\title{
Short-term ecophysiological and biochemical responses of Cystoseira tamariscifolia and Ellisolandia elongata to environmental changes
}

\author{
P. S. M. Celis-Plá1,2,* , B. Martínez ${ }^{3}$, E. Quintano ${ }^{4}$, M. García-Sánchez ${ }^{5}$, A. Pedersen ${ }^{6}$, \\ N. P. Navarro ${ }^{7}$, M. S. Copertino ${ }^{8}$, N. Mangaiyarkarasi ${ }^{9}$, R. Mariath ${ }^{10}$, F. L. Figueroa ${ }^{1}$, N. Korbee ${ }^{1}$ \\ ${ }^{1}$ Department of Ecology, Faculty of Science, University of Málaga, 29071 Málaga, Spain \\ ${ }^{2}$ Laboratory of Botany, Faculty of Pharmacy, University of Barcelona, 08028 Barcelona, Spain \\ ${ }^{3}$ Biology and Geology Department, Rey Juan Carlos University, 28933 Móstoles, Spain \\ ${ }^{4}$ Department of Plant Biology and Ecology, Faculty of Science and Technology, University of the Basque Country (UPV/EHU), \\ PO Box 644, 48080 Bilbao, Spain \\ ${ }^{5}$ Department of Ecology and Hydrology, Faculty of Biology, Regional Campus of International Excellence 'Campus Mare Nostrum', \\ University of Murcia, 30100 Murcia, Spain \\ ${ }^{6}$ Norwegian Institute for Water Research, Department of Marine Biology, 0349 Oslo, Norway \\ ${ }^{7}$ Faculty of Science, University of Magallanes, Casilla 113-D, Punta Arenas, Chile \\ ${ }^{8}$ Institute of Oceanography, Federal University of Rio Grande-FURG, c.p. 474, cep 93206-900 Rio Grande (RS), Brazil \\ ${ }^{9}$ Plant Biology and Biotechnology, CKN College Thiruvalluvar University, India \\ ${ }^{10}$ Department of Botany, Institute of Biology, Federal University of Rio de Janeiro, Brazil
}

\begin{abstract}
Short-term ecophysiological and biochemical responses of Cystoseira tamariscifolia and Ellisolandia elongata to changes in solar irradiance and nutrient levels were analyzed in situ in oligotrophic coastal waters by transferring macroalgae collected at 0.5 and $2.0 \mathrm{~m}$ depth and exposing them to 2 irradiance levels (100 and $70 \%$ of surface irradiance) and nutrient conditions (nutrient-enriched and non-enriched). Both species were affected by changes in irradiance and nutrient levels. Few interactive effects between these 2 physical stressors were found, suggesting major additive effects on both species. C. tamariscifolia collected at $0.5 \mathrm{~m}$ and exposed to $70 \%$ irradiance had the highest maximal electron transport rate $\left(\mathrm{ETR}_{\max }\right)$, saturated irradiance $\left(E k_{\mathrm{ETR}}\right)$ and chl a content and the lowest antioxidant activity. Under the same conditions, E. elongata had increased $E k_{\mathrm{ETR}}$, antheraxanthin and $\beta$-carotene content. At $100 \%$ irradiance, $C$. tamariscifolia collected at $2.0 \mathrm{~m}$ had higher maximal quantum yield $\left(F_{\mathrm{v}} / F_{\mathrm{m}}\right)$, photosynthetic efficiency $\left(\alpha_{\mathrm{ETR}}\right)$, $\mathrm{ETR}_{\max }$, maximal non-photochemical quenching $\left(\mathrm{NPQ}_{\max }\right)$, saturation irradiance for NPQ $\left(E k_{\mathrm{NPQ}}\right)$, and antheraxanthin and polyphenol content increased, whereas in E. elongata only $\alpha_{\mathrm{ETR}}$ increased. In nutrient-enriched conditions, phenolic compounds, several carotenoids and $\mathrm{N}$ content increased in C. tamariscifolia at both depths. E. elongata from $2.0 \mathrm{~m}$ depth at $100 \%$ irradiance and nutrient-enriched conditions showed increased $\mathrm{N}$ content and total mycosporine-like amino acids (MAAs). Our results show rapid photophysiological responses of $C$. tamariscifolia to variations in in situ irradiance and nutrient conditions, suggesting efficient photoacclimation to environmental changes. In E. elongata, $F_{\mathrm{v}} / F_{\mathrm{m}}$ and $\mathrm{ETR}_{\max }$ did not change in the transplant experiment; in contrast, $\mathrm{N}$ content, pigment and MAAs (biochemical variables) changed. The responses of these macroalgae to nutrient enrichment indicate oligotrophic conditions at the study site and environmental stress.
\end{abstract}

KEY WORDS: Cystoseira tamariscifolia · Ellisolandia elongata · Antioxidant activity · Carotenoids · Irradiance $\cdot$ Nutrient $\cdot$ Polyphenols $\cdot$ Photoprotection 


\section{INTRODUCTION}

Environmental stressors can interact and have synergistic or antagonistic effects on physiological responses (Bischof et al. 2006). When multiple stressors act synergistically, there can be unpredictable effects on organisms (Xenopoulos et al. 2002). In contrast, when stressors operate in an additive way, species' responses are easier to predict (Martínez et al. 2012). It is important to understand the mechanisms of combined environmental stressors in order to predict an organism's responses to future climate scenarios. Experimental transplants can provide a better understanding of such effects (Marzinelli et al. 2009, 2011) .

Benthic intertidal organisms are subjected to major changes during the tidal cycle (Davison \& Pearson 1996). The responses of intertidal and benthic organisms to stressors can be very rapid, and involve adjustments in their photosynthetic and respiratory activities (Southward et al. 1995, HoeghGuldberg \& Bruno 2010, Sorte et al. 2010). Temperate intertidal rocky communities can be dominated by habitat-forming macroalgae that drive the biodiversity and functioning of these ecosystems. The algae provide food and shelter, and also reduce environmental stress (Davison \& Pearson 1996, Jones 1997, Helmuth et al. 2002, 2006). However, the increasing environmental stresses associated with climatic changes and anthropogenic impacts (e.g. coastal eutrophication, increase in UV light) can affect macroalgal communities at the biochemical, ecophysiological, morphological and population levels (Figueroa \& Gómez 2001, Bischof et al. 2006).

Light availability is a key factor affecting marine environments (Huovinen \& Gómez 2011). Light promotes photosynthetic activity, but can inhibit many biological processes if radiation becomes excessive (Hanelt \& Figueroa 2012). Macroalgae have several photoprotective mechanisms such as energy dissipation by specific pigments (e.g. carotenoids) through the xanthophyll cycle (Goss \& Jakob 2010); dynamic photoinhibition, i.e. reversible changes in photosynthetic efficiency and capacity, accumulation of ultraviolet screen compounds and increase of antioxidant activity (Gómez et al. 2011). For instance, brown algae accumulate UV screen compounds (polyphenols) with a strong antioxidant activity under high photosynthetically active radiation (PAR) and UVR (Pavia et al. 1997, Connan et al. 2004, Cruces et al. 2012), whereas the tolerance of most red algae to excessive light, including UV, is driven by the accumulation of myco- sporine-like amino acids (MAAs) (de la Coba et al. 2009).

Nutrient availability is another environmental factor limiting macrophyte growth in temperate and oligotrophic habitats (Hanisak 1979, Conolly \& Drew 1985). Nitrogen limitation affects many processes in macroalgae including photosynthetic capacity (PérezLloréns et al. 1996), protein content (Vergara et al. 1995, Martínez \& Rico 2002) and photoprotection mechanisms (Korbee-Peinado et al. 2004, Korbee et al. 2005b, Huovinen et al. 2006). Under moderate to highly desiccated conditions, some intertidal macroalgae increase their nitrogen and carbon uptake (Lobban \& Harrison 1994, Flores-Moya et al. 1998, Nygard \& Dring 2008). In terms of nutrient metabolism and nutrition, macroalgae vary according to their growth strategies (Lobban \& Harrison 1994, Pedersen \& Borum 1997). On one side, slow-growing perennial macroalgae, adapted to stable or seasonally variable $\mathrm{N}$ conditions, can develop large $\mathrm{N}$ and $\mathrm{P}$ storage pools (Martínez et al. 2012). At the another extreme, fast-growing opportunistic algae are unable to store large amounts, but show remarkably high $\mathrm{N}$ - and $\mathrm{P}$ uptake rates to profit from unstable $\mathrm{N}$-supply conditions (Teichberg et al. 2008). Finally, nutrient enrichment increases the photoprotection capacity of seaweeds due to the increase in protein content, MAAs (Korbee-Peinado et al. 2004, Huovinen et al. 2006, Figueroa et al. 2012) or polyphenols (Arnold \& Targett 2002).

Cystoseira tamariscifolia Papenfuss (Phaeophyceae, Fucales) and Ellisolandia elongata (Ellis \& Solander) Hind \& Saunders (Florideophyceae, Corallinales) are 2 important species on Mediterranean rocky shores. Cystoseira spp. are indicators of high quality coastal waters (Arévalo et al. 2007, Ballesteros et al. 2007, Bermejo et al. 2013), according to the criteria of the Water Framework Directive of the European Union (WFD, 2000/60/EC). E. elongata is a stress-tolerant, calcareous species dominating zones subjected to disturbance.

In this study, the physiological and biochemical responses of C. tamariscifolia and E. elongata, collected from 2 different depths, were investigated in relation to the independent and/or interactive effects of ambient radiation and nutrient availability. Based on previous research on the additive effects of physical stressors on fucoid algae (Martínez et al. 2012), we hypothesized that changes in light and nitrogen will have an additive effect on C. tamariscifolia and E. elongata. Algae collected from $0.5 \mathrm{~m}$ depth and under nutrient enriched conditions were expected to be less vulnerable under the transplant conditions. 


\section{MATERIALS AND METHODS}

\section{Studied species}

Cystoseira tamariscifolia is a habitat-forming species that dominates intertidal and shallow-subtidal Mediterranean communities in pristine sites and oligotrophic waters. Although this is a perennial species, receptacles are most developed in spring and summer (Gómez-Garreta et al. 2001). Ellisolandia elongata is an articulated calcareous species that dominates benthic intertidal communities replaced by ulvacean algae at intermediate levels of nutrient enrichment (Arévalo et al. 2007). Resembling a small bush and up to $20 \mathrm{~cm}$ in height (Braga et al. 2009), it is a perennial species and can occupy both well-lit and shaded habitats (Algarra \& Niell 1987, Häder et al. 1997, Figueroa \& Gómez 2001). It has been recorded to be in the fertile tetrasporophyte phase throughout the year (Rodríguez \& Polo 1986).

\section{Experimental design}

The experiment was performed from September 19 to 21, 2012. C. tamariscifolia and E. elongata were randomly collected from 2 different depths $(0.5$ and 2.0 m) (Fig. 1a) at the 'Cabo de Gata-Níjar' Natural
Park (3651' 0" N; $2^{\circ} 6^{\prime} 0^{\prime \prime} \mathrm{W}_{\text {; }}$ southwestern Mediterranean Sea, Spain). Immediately after collection, macroalgal samples (5 $\mathrm{g}$ fresh weight [FW]) were placed into mesh cylinders $(15 \mathrm{~cm}$ long $\times 5 \mathrm{~cm}$ in diameter) and suspended in the water column (at a depth of $0.2 \mathrm{~m}$ ) by a floating longline system anchored to the bottom and parallel to the coast (Fig. 1b). This system comprised 4 lines of $12 \mathrm{~m}$ length. Each line contained 12 cylinders (separated by $1 \mathrm{~m})$. Two lines were placed at one site for the enriched nitrogen treatment and the other 2 lines were placed at another site for the non-enrichment treatment (Fig. 1b). Both sites were separated by $50 \mathrm{~m}$ with a small artificial breakwater between them. Each cylinder contained specimens of one unique species and collection depth (in triplicate) was fixed along each line (Fig. 1c). Two light levels were assigned within each treatment, i.e. 70 and $100 \%$ of surface irradiance defined as PAB irradiance (PAR + UVR) under nutrient-enriched and non-enriched conditions (Fig. 1c). With regard to the irradiance treatment, a neutral screen was used which attenuates $30 \%$ of the incident light. Half of the cylinders (containing algae from both depths) were covered with mesh $\left(1 \mathrm{~mm}^{2}\right)$ to attain $70 \%$ incoming irradiance (simulating conditions at a depth of $2.0 \mathrm{~m}$, thereafter $\left.70 \%{ }_{\mathrm{PAB}}\right)$, and the remaining cylinders were without the screen to attain $100 \%$ incoming irradiance a

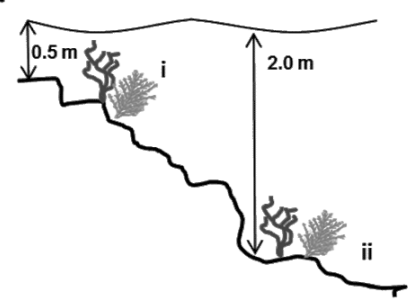

b

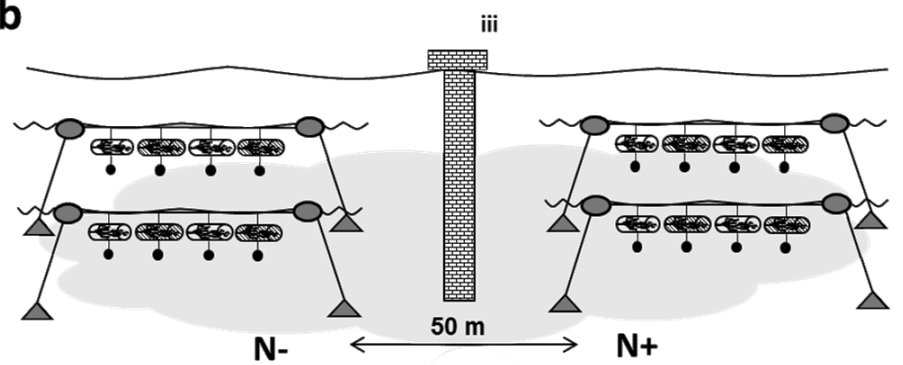

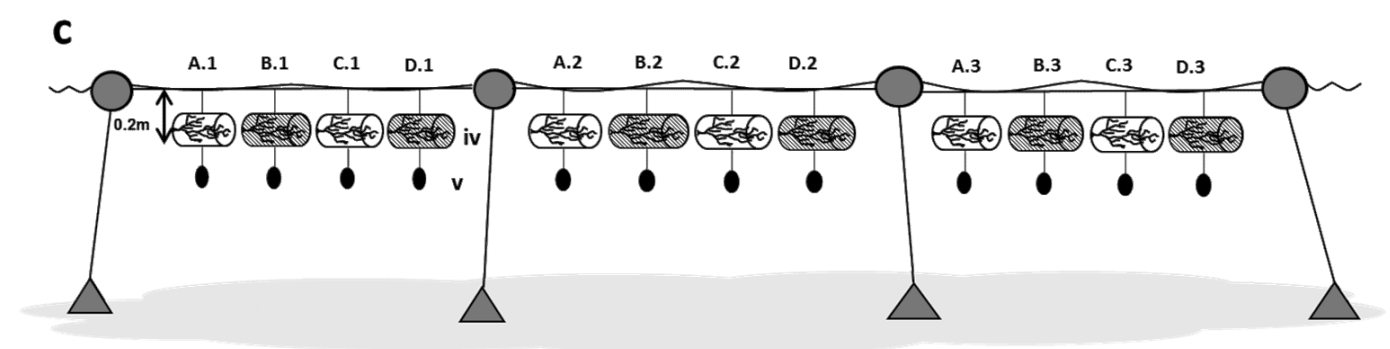

Fig. 1. (a) Depths of origin (i: 0.5 m; ii: $2.0 \mathrm{~m}$ ) of both collected species Cystoseira tamariscifolia and Ellisolandia elongata. (b) Schematic layout of the floating lines system separated by a physical barrier (iii: breakwater) comprising 4 longline systems $50 \mathrm{~m}$ apart for each treatment. $\mathrm{N}+$ and $\mathrm{N}$ - indicate nutrient-enriched and non-enriched treatments, respectively. (c) Schematic layout of one floating line system for each macroalgae with 12 cylinders (iv: cylinder; v: bag with fertilizer or sand). White cylinders (A.1, A.2, A.3, C.1, C.2 and C.3) indicate $100 \%_{\mathrm{PAB}}$ treatment with all replicates, and grey cylinders (B.1, B.2, B.3, D.1, D.2 and D.3) indicate $70 \%_{\mathrm{PAB}}$ with all replicates for both depths 
(simulating a depth of $0.5 \mathrm{~m}$, thereafter $100 \%{ }_{\mathrm{PAB}}$ ). Thereby, algae collected at $0.5 \mathrm{~m}$ depth (shallow waters) were exposed to $70 \% \mathrm{PAB}$ (as a transplant treatment) and $100 \%_{\mathrm{PAB}}$ (as a control of natural conditions at $0.5 \mathrm{~m}$ depth). On the other hand, those algae collected at $2.0 \mathrm{~m}$ depth were exposed to $100 \%_{\mathrm{PAB}}$ (as a transplant treatment) and $70 \%$ рАВ (as a control of natural conditions at $2.0 \mathrm{~m}$ depth) (Fig. 1b). For the nutrient-enriched treatments, mesh bags containing $100 \mathrm{~g}$ of a slow-release resin-coated fertilizer (Multicote ${ }^{\circledR}$, Haifa Chemicals) (modified from Martínez et al. 2012) and fixed below each cylinder was used to simulate nutrient enrichment. Fertilizer composition was $17 \% \mathrm{~N}\left(\mathrm{NH}_{4}{ }^{+}\right.$and $\left.\mathrm{NO}_{3}{ }^{-}\right), 17 \% \mathrm{P}\left(\mathrm{P}_{2} \mathrm{O}_{5}\right)$ and $17 \%$ K. For non-enriched treatments, a neutral bag with $100 \mathrm{~g}$ of sand was used as a control of the effect of the fertilizer bag and the modifying buoyancy (Fig. 1b).

Three replicate cylinders were used for each combination of treatment level, species and depth $(2$ species $\times 2$ depths $\times 2$ irradiance levels $\times 2$ nutrient levels), resulting in a total of 48 cylinders with macroalgal samples (Fig. 1b). Several physiological variables were obtained from the algae within each cylinder after the in situ experiment. These variables were also measured in C. tamariscifolia and E. elongata from natural populations (at 0.5 and $2.0 \mathrm{~m}$ depth) in order to know the initial values. Additionally, water nutrient concentrations, irradiance (PAR and UVR) and underwater temperature were measured during the experiment.

\section{Environmental conditions}

Nutrient enrichment ( $\mathrm{N}$ and $\mathrm{P}$ ) through fertilizer was assessed by taking triplicate seawater samples at both enriched and non-enriched sites. Seawater was filtered in situ using portable GF/F filters (Whatman), transported to the laboratory inside an isotherm bag $\left(4^{\circ} \mathrm{C}\right.$, in darkness) and kept at $-20^{\circ} \mathrm{C}$ (Martínez et al. 2012). Nitrate $\left(\mathrm{NO}_{3}{ }^{-}\right)$, ammonium $\left(\mathrm{NH}_{4}{ }^{+}\right)$and orthophosphate $\left(\mathrm{HPO}_{4}{ }^{3-}\right)$ were determined using an automated wet chemistry analyzer (SanPlus ${ }^{++}$System, SKALAR) applying standard colorimetric procedures (Koroleff 1983).

Irradiance of solar radiation was continuously measured in the air at 3 wavelength bands (UVB = $280-315 \mathrm{~nm}, \mathrm{UVA}=315-400 \mathrm{~nm}$ and PAR $=400-700$ $\mathrm{nm}$ ) using 2 hyperspectral irradiance sensors for UV and PAR (Ramses, TrioS). Attenuation coefficients in water $\left(K d_{\mathrm{PAR}}\right.$ and $\left.K d_{\mathrm{UVA}}\right)$ were measured using PAR (QSO-SUN 2.5V) and UV-R (USB-SU 100, Onset Computer) sensors sealed within a waterproof poly- carbonate box (OtterBox3000). $K d_{\text {UvB }}$ was not measured due to the high absorption of the polycarbonate box in the UVB spectral band (Quintano et al. 2013).

Underwater temperature was continuously measured using a HOBO U22 Water Temp Pro v2 logger (Onset Computer).

\section{Physiological and biochemical variables}

Carbon and nitrogen contents on a dry weight (DW) basis were determined using an element analyzer CNHS-932 (LECO).

In vivo chlorophyll a ( $\mathrm{chl}$ a) fluorescence associated with Photosystem II (PSII) was determined by using a portable pulse amplitude modulated fluorometer Diving-PAM (Walz). Algal pieces were collected from natural populations (initial time) and after $60 \mathrm{~h}$ of incubation (for each cylinder) and were placed in $10 \mathrm{ml}$ incubation chambers in order to conduct rapid light curves, one for each cylinder. $F_{\mathrm{o}}$ and $F_{\mathrm{m}}$ were determined after $15 \mathrm{~min}$ in darkness to obtain the maximum quantum yield $\left(F_{\mathrm{v}} / F_{\mathrm{m}}\right)$, where $F_{\mathrm{v}}=F_{\mathrm{m}}-F_{\mathrm{o}}, F_{\mathrm{o}}$ is the basal fluorescence of dark-adapted thalli after 15 min and $F_{\mathrm{m}}$ is the maximal fluorescence after a saturation light pulse of $>4000 \mu \mathrm{mol} \mathrm{m}^{-2} \mathrm{~s}^{-1}$ (Schreiber et al. 1995, Figueroa et al. 2009). The electron transport rate (ETR, $\mu$ mol electrons $\mathrm{m}^{-2} \mathrm{~s}^{-1}$ ) as rapid light curves (RLC) was determined after a $20 \mathrm{~s}$ exposure period in 8 increasing irradiances $(\mathrm{E} 1=9.3, \mathrm{E} 2=33.8, \mathrm{E} 3=76$, $\mathrm{E} 4=145, \mathrm{E} 5=217, \mathrm{E} 6=301, \mathrm{E} 7=452, \mathrm{E} 8=629, \mathrm{E} 9=$ $947 \mu \mathrm{mol} \mathrm{m} \mathrm{m}^{-2} \mathrm{~s}^{-1}$ ) of white light (halogen lamp provided by the Diving-PAM). ETR was calculated according to Schreiber et al. (1995) as follows:

$$
\mathrm{ETR}=\Delta F / F_{\mathrm{m}}{ }^{\prime} \times E \times A \times F_{\text {II }}
$$

where $\Delta F / F_{\mathrm{m}}{ }^{\prime}$ is the effective quantum yield, $\Delta F=F_{\mathrm{m}}{ }^{\prime}$ $-F_{t}\left(F_{t}\right.$ is the intrinsic fluorescence of alga incubated in light and $F_{\mathrm{m}}$ ' is the maximal fluorescence reached after a saturation pulse of algae incubated in light), $E$ is the incident PAR irradiance expressed in $\mu \mathrm{mol}$ photons $\mathrm{m}^{-2} \mathrm{~s}^{-1}, A$ is the thallus absorptance as the fraction of incident irradiance that is absorbed by the algae (see Figueroa et al. 2003) and $F_{\text {II }}$ is the fraction of chlorophyll related to PSII (400-700 $\mathrm{nm}$ ), being 0.8 in brown and 0.15 in red macroalgae (Grzymski et al. 1997, Figueroa et al. 2003). Maximum ETR (ETR $\max$ ) and the initial slope of ETR versus irradiance function $\left(\alpha_{\mathrm{ETR}}\right)$, as an estimator of photosynthetic efficiency, were obtained from the tangential function reported by Eilers \& Peeters (1988). Finally, the saturation irradiance for ETR $\left(E k_{\mathrm{ETR}}\right)$ was calculated from the intercept between $\mathrm{ETR}_{\max }$ and $\alpha_{\mathrm{ETR}}$. 
Non-photochemical quenching (NPQ) was calculated according to Schreiber et al. (1995) as:

$$
\mathrm{NPQ}=\left(F_{\mathrm{m}}-F_{\mathrm{m}}{ }^{\prime}\right) / F_{\mathrm{m}}{ }^{\prime}
$$

Maximal NPQ $\left(\mathrm{NPQ}_{\max }\right)$ and the initial slope of NPQ versus irradiance function $\left(\alpha_{\mathrm{NPQ}}\right)$ were obtained from the tangential function of NPQ versus irradiance function according to Eilers \& Peeters (1988). Finally, the saturation irradiance for NPQ $\left(E k_{\mathrm{NPQ}}\right)$ was calculated from the intercept between $\mathrm{NPQ}_{\max }$ and $\alpha_{\mathrm{NPQ}}$.

$\mathrm{Chl} a$ and carotenoid pigments were determined in both species, whereas chlorophyll $C(\mathrm{chl} C)$ only in C. tamariscifolia and phycobiliproteins only in E. elongata.

Chl a was determined spectrophotometrically, whilst chl $C$ was identified and quantified using HPLC. Both chlorophyll analyses were made by extracting pigments from thalli (25 mg FW) using $1 \mathrm{ml}$ of $\mathrm{N}, \mathrm{N}$-dimethylformamide (DMF) and maintained in darkness at $4^{\circ} \mathrm{C}$ for $12 \mathrm{~h}$. After centrifugation at $5000 \times g$ for $10 \mathrm{~min}$ (Labofuge 400R, Heraeus, Kendro Laboratory Products), each supernatant was used to measure chlorophyll spectrophotometrically. In the case of $\mathrm{chl} c$, the extracts were filtered $(0.2 \mu \mathrm{M})$ before analyzing with HPLC. The chlorophyll concentrations were calculated using equations by Wellburn (1994). Carotenoid composition was determined by HPLC according to García-Sánchez et al. (2012), using commercial standards (DHI LAB Products).

Phycobiliproteins of E. elongata were extracted in $0.1 \mathrm{M}$ phosphate buffer $(\mathrm{pH}$ 6.5), centrifuged at $2253 \times \mathrm{g}$ for $30 \mathrm{~min}$ at $4^{\circ} \mathrm{C}$. Phycoerythrin (PE) and phycocyanin $(\mathrm{PC})$ concentrations were calculated following Sampath-Wiley \& Neefus (2007) equations.

Total phenolic compounds (polyphenols) were determined only in C. tamariscifolia using $0.25 \mathrm{~g} \mathrm{FW}$. Samples were pulverized in a mortar and pestle with sea sand using $2.5 \mathrm{ml}$ of $80 \%$ methanol. After keeping the samples overnight, the mixture was centrifuged at $2253 \times g$ for $30 \mathrm{~min}$ at $4^{\circ} \mathrm{C}$, and then the supernatant was collected. Total phenolic compounds were determined colorimetrically using Folin-Ciocalteu reagent (Folin \& Ciocalteu 1927) and phloroglucinol (1,3,5-trihydroxybenzene, Sigma P3502) as standard. Finally, the absorbance was determined at $760 \mathrm{~nm}$ using a Shimadzu UVMini-1240 spectrophotometer. Phenolic concentration was expressed as $\mathrm{mg} \mathrm{g}^{-1} \mathrm{DW}$ after determining the fresh to dry weight ratio in the tissue (4.3 and 1.5 for $C$. tamariscifolia and E. elongata, respectively). The results are expressed as mean \pm SE from 3 replicates of each treatment.
Antioxidant activity, determined by the 2,2diphenyl-1-picrylhydrazyil (DPPH) method, was measured on the polyphenol compound extracts according to Blois (1958). Each extract had $150 \mu \mathrm{l}$ of $\mathrm{DPPH}$, prepared in $90 \%$ methanol, added. The reaction was complete after 30 min in darkness at ambient temperature $\left(\sim 20^{\circ}\right)$, and the absorbance was read at $517 \mathrm{~nm}$ in a spectrophotometer UVmini-1240 (Shimadzu). The calibration curve made from DPPH was used to calculate the remaining concentration of DPPH in the reaction mixture after incubation. Values of DPPH concentration $(\mathrm{mM})$ were plotted against plant extract concentration $\left(\mathrm{mg} \mathrm{DW} \mathrm{ml}^{-1}\right)$ in order to obtain the $\mathrm{EC}_{50}$ value (oxidation index), which represents the concentration of the extract (mg $\mathrm{ml}^{-1}$ ) required to scavenge $50 \%$ of the DPPH in the reaction mixture. Ascorbic acid was used as a positive control (Connan et al. 2006).

Total MAA content was determined only in E. elongata using HPLC (Waters 600) as described by Korbee-Peinado et al. (2004). Results were expressed as $\mathrm{mg} \mathrm{g}^{-1} \mathrm{DW}$ after determining the fresh to dry weight ratio in the tissue (1.5 for E. elongata).

\section{Statistical analysis}

The effects of the in situ treatments on the ecophysiological response variables of $C$. tamariscifolia and $E$. elongata were assessed using ANOVA (Underwood 1997). For that purpose, 2 factors were considered: Nutrient (fixed with 2 levels) and Irradiance (fixed with 2 levels). This design allows the testing of interactive and additive effects of the variables on the ecophysiological responses. Data used in the analyses were those obtained at the end of the experimental period (after $60 \mathrm{~h}$ of photoacclimation). StudentNewman-Keuls tests (SNK) were performed after significant ANOVA interactions (Underwood 1997). Homogeneity of variance was tested using Cochran tests and by visual inspection of the residuals. Analyses were performed by using SPSS v.21 (IBM).

\section{RESULTS}

\section{Environmental conditions}

Nitrate $\left(\mathrm{NO}_{3}{ }^{-}\right)$, ammonium $\left(\mathrm{NH}_{4}{ }^{+}\right)$and phosphate $\left(\mathrm{PO}_{4}{ }^{3-}\right)$ concentrations at the non-enriched site were $1.34 \pm 0.31 \mu \mathrm{M}, 1.17 \pm 0.35 \mu \mathrm{M}$ and $0.09 \pm 0.01 \mu \mathrm{M}$, respectively. In contrast, concentrations at the nutrient-enriched site were $107.51 \pm 9.67 \mu \mathrm{M}, 163.31$ 
$\pm 6.10 \mu \mathrm{M}$ and $24.52 \pm 1.51 \mu \mathrm{M}$, respectively (mean \pm $\mathrm{SE}, \mathrm{n}=6)$. Hence, on average, the nutrient-enriched treatment increased nitrate, ammonium and phosphate concentrations in the water column by 80,139 and 272 times, respectively. The average daily integrated surface irradiance for the experimental period (September 20 and 21, 2012) was $5842 \mathrm{KJ} \mathrm{m}^{-2}$ for PAR, $673.3 \mathrm{KJ} \mathrm{m}^{-2}$ for UVA and $27.3 \mathrm{KJ} \mathrm{m}^{-2}$ for UVB. The attenuation coefficients for PAR $\left(K d_{\mathrm{PAR}}\right)$ and UVA ( $\left.K d_{\mathrm{UVA}}\right)$ were $0.076 \mathrm{~m}^{-1}$ and $0.137 \mathrm{~m}^{-1}$, respectively. The average seawater temperature at $0.2 \mathrm{~m}$ (mean $\pm \mathrm{SE}, \mathrm{n}=1440$ ) ranged between $24.42 \pm 0.42^{\circ} \mathrm{C}$ (during the day) and $23.8 \pm 0.19^{\circ} \mathrm{C}$ (at night).

\section{Physiological response variables}

Internal $\mathrm{N}$ content was higher in Cystoseira tamariscifolia than in Ellisolandia elongata (Table 1, Fig. 2). ANOVA results showed that both species from $0.5 \mathrm{~m}$ depth presented significantly higher $\mathrm{N}$ content and a lower $\mathrm{C}: \mathrm{N}$ ratio under the nutrient-enriched treatment (Table 1, Figs. 2 \& 3). However, the $\mathrm{N}$ content from 2.0 $m$ depth samples was different for both species (Table 1, Fig. 2). C. tamariscifolia specimens collected from $2.0 \mathrm{~m}$ showed similar $\mathrm{N}$ content to those from $0.5 \mathrm{~m}$ and the $\mathrm{C}: \mathrm{N}$ ratio increased under the non-enriched treatments (Figs. 2a \& 3a). In contrast, E. elongata showed a significant interaction between nutrients and irradiance (Table 1). $\mathrm{N}$ content in the nutrient-enriched treatment was lower under the $100 \%_{\mathrm{PAB}}$ treatments and the C:N ratio was higher under the same conditions (Figs. 2b \& 3b).

$F_{\mathrm{v}} / F_{\mathrm{m}}$ in C. tamariscifolia showed a significant interaction with nutrients and irradiance in algae

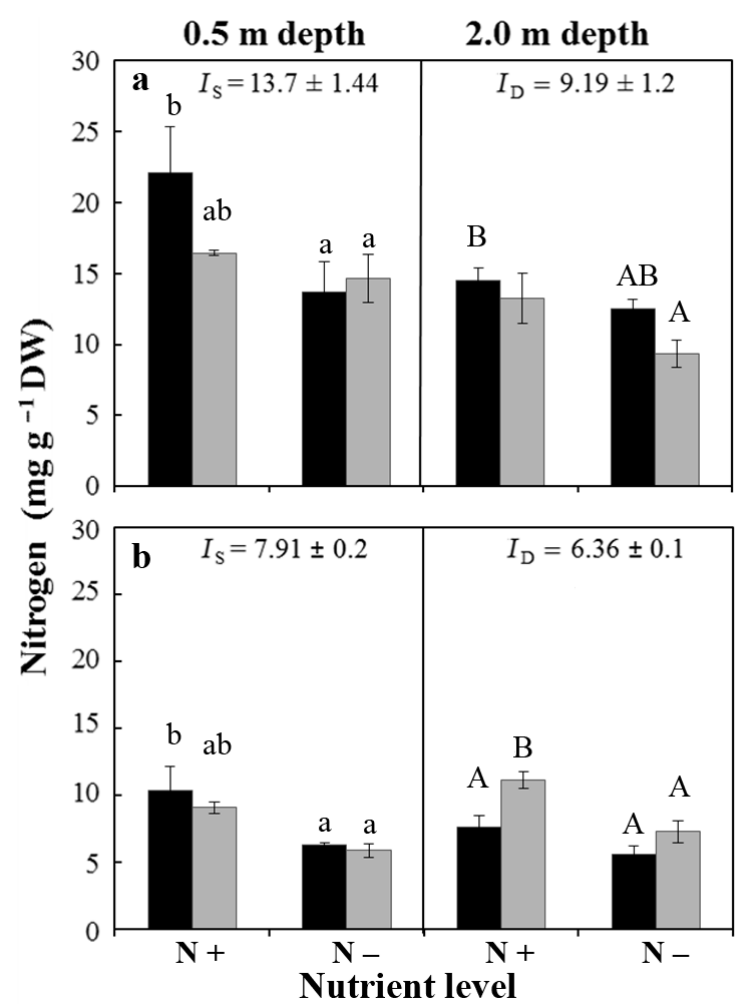

Fig. 2. Total internal $\mathrm{N}$ content (mean $\pm \mathrm{SE}, \mathrm{n}=3$ ) of (a) Cystoseira tamariscifolia and (b) Ellisolandia elongata from 0.5 and $2.0 \mathrm{~m}$ depth under irradiance and nutrient treatments. Black bars indicate $100 \% \%_{\mathrm{PAB}}$, and grey bars indicate $70 \%_{\mathrm{PAB}}$. N+ and N- indicate nutrient-enriched and nonenriched treatments, respectively. Upper values in each box indicate initial values ( $I_{\mathrm{S}}: 0.5 \mathrm{~m}$ depth; $I_{\mathrm{D}}: 2.0 \mathrm{~m}$ depth). Lowercase letters denote significant differences after SNK test for $0.5 \mathrm{~m}$ and capital letters for $2.0 \mathrm{~m}$ algae

collected at $2.0 \mathrm{~m}$ depth (Table 2). Specimens of C. tamariscifolia transplanted to $100 \%$ РАв presented higher $F_{\mathrm{v}} / F_{\mathrm{m}}$ under non-enriched treatments (Table 3). Neither of the species collected at $0.5 \mathrm{~m}$

Table 1. ANOVA results after in situ experiment testing for the effect of irradiance and nutrients on $\mathrm{C}$ and $\mathrm{N}$ contents and $\mathrm{C}: \mathrm{N}$ ratios of Cystoseira tamariscifolia and Ellisolandia elongata collected at 2 different depths. We used a significance level of $\alpha=0.05$, shown in bold

\begin{tabular}{|c|c|c|c|c|c|c|c|c|c|c|c|c|c|c|}
\hline & & \multirow[t]{3}{*}{ df } & \multicolumn{6}{|c|}{ Cystoseira tamariscifolia } & \multicolumn{6}{|c|}{ Ellisolandia elongata } \\
\hline & & & \multicolumn{3}{|c|}{$0.5 \mathrm{~m}$ depth } & \multicolumn{3}{|c|}{$2.0 \mathrm{~m}$ depth } & \multicolumn{3}{|c|}{$0.5 \mathrm{~m}$ depth } & \multicolumn{3}{|c|}{$2.0 \mathrm{~m}$ depth } \\
\hline & & & MS & $F^{1}$ & $\mathrm{p}$ & MS & $F$ & $\mathrm{p}$ & MS & $F^{2}$ & $\mathrm{p}$ & MS & $F^{1}$ & $\mathrm{p}$ \\
\hline \multirow[t]{4}{*}{$\mathrm{C}$} & Nutrients $(N)$ & 1 & 75.5 & 0.276 & 0.613 & 753.7 & 1.366 & 0.276 & 561.7 & 5.805 & 0.043 & 149.1 & 1.400 & 0.271 \\
\hline & Irradiance $(E)$ & 1 & 27.9 & 0.102 & 0.758 & 2578.4 & 4.672 & 0.063 & 25.5 & 0.264 & 0.621 & 231.4 & 2.173 & 0.179 \\
\hline & $N \times E$ & 1 & 144.9 & 0.530 & 0.487 & 108.6 & 0.197 & 0.669 & 2.2 & 0.022 & 0.885 & 744.2 & 6.987 & 0.030 \\
\hline & Residual & 8 & 273.4 & & & 551.8 & & & 96.8 & & & 106.5 & & \\
\hline \multirow[t]{4}{*}{$\mathrm{N}$} & Nutrients $(N)$ & 1 & 77.6 & 5.625 & 0.045 & 25.8 & 6.639 & 0.033 & 39.9 & 14.145 & 0.006 & 25.6 & 15.540 & 0.004 \\
\hline & Irradiance $(E)$ & 1 & 16.1 & 1.163 & 0.312 & 14.9 & 3.836 & 0.086 & 2.1 & 0.753 & 0.411 & 20.3 & 12.321 & 0.008 \\
\hline & $N \times E$ & 1 & 32.9 & 2.382 & 0.161 & 2.7 & 0.695 & 0.429 & 0.5 & 0.189 & 0.675 & 2.5 & 1.543 & 0.249 \\
\hline & Residual & 8 & 13.8 & & & 3.9 & & & 2.8 & & & 1.6 & & \\
\hline \multirow[t]{4}{*}{$\mathrm{C}: \mathrm{N}$} & Nutrients $(N)$ & 1 & 103.6 & 5.098 & 0.054 & 154.7 & 5.962 & 0.040 & 132.0 & 23.959 & 0.001 & 182.8 & 11.883 & 0.009 \\
\hline & Irradiance $(E)$ & 1 & 0.5 & 0.023 & 0.884 & 27.2 & 1.047 & 0.336 & 10.1 & 1.830 & 0.213 & 149.6 & 9.723 & 0.014 \\
\hline & $N \times E$ & 1 & 39.9 & 1.963 & 0.199 & 18.5 & 0.712 & 0.423 & 0.0 & 0.006 & 0.941 & 10.3 & 0.668 & 0.437 \\
\hline & Residual & 8 & 20.3 & & & 26.0 & & & 5.5 & & & 15.4 & & \\
\hline
\end{tabular}




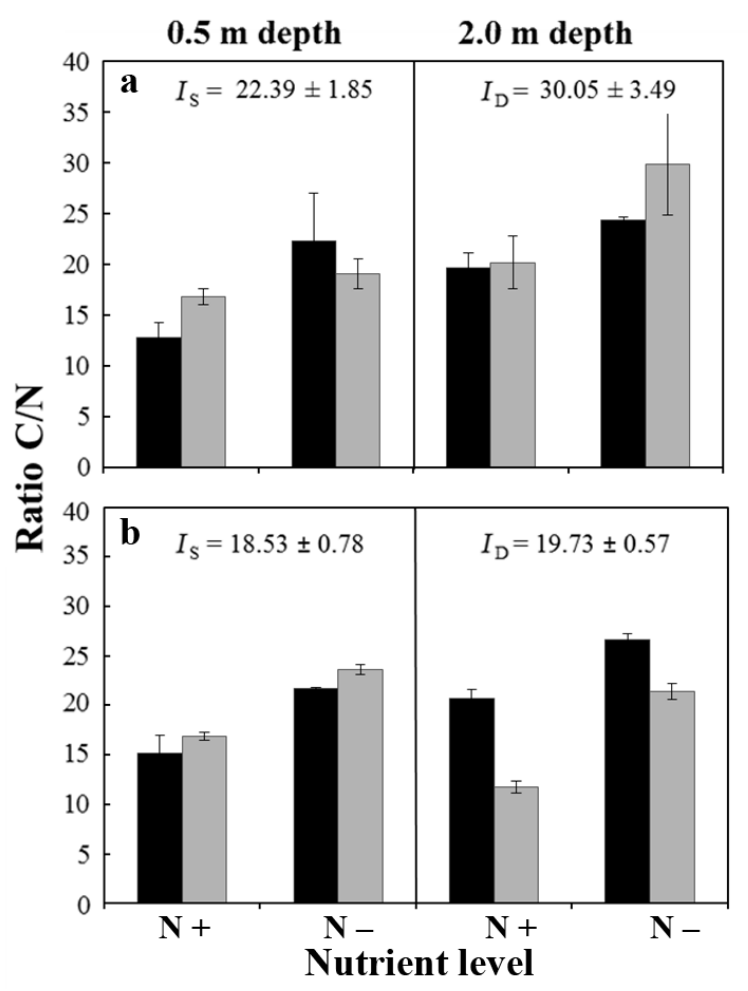

Fig. 3. C:N ratio (mean $\pm \mathrm{SE}, \mathrm{n}=3$ ) of (a) Cystoseira tamariscifolia and (b) Ellisolandia elongata from 0.5 and $2.0 \mathrm{~m}$ depth under irradiance and nutrient treatments. Black bars indicate $100 \%{ }_{\mathrm{PAB}}$, and grey bars indicate $70 \%{ }_{\mathrm{PAB}} . \mathrm{N}+$ and $\mathrm{N}-$ indicate nutrient-enriched and nonenriched treatments, respectively. Upper values in each box indicate initial values $\left(I_{\mathrm{S}}: 0.5 \mathrm{~m}\right.$ depth; $I_{\mathrm{D}}: 2.0 \mathrm{~m}$ depth)

nor E. elongata at $2.0 \mathrm{~m}$ showed significant differences (Table 2). In contrast, $\mathrm{ETR}_{\max }$ of C. tamariscifolia showed significant differences among irradiance treatments $\left(70 \%_{\mathrm{PAB}}\right.$ and $\left.100 \%_{\mathrm{PAB}}\right)$ at $0.5 \mathrm{~m}$ depth (Table 2). This value was higher when they were transplanted to $70 \%$ PAB (Table 3). Conversely, specimens of both species collected at $2.0 \mathrm{~m}$ depth did not show any significant differences for either depth. $\alpha_{\mathrm{ETR}}$ in $C$. tamariscifolia showed a significant interaction with nutrients and irradiances at both depths (Table 2). This value was lower at $70 \%$ PAB (transplant treatment) and non-nutrient enriched conditions. In both cases, $\alpha_{\text {ETR }}$ equaled initial observations from its natural habitat after incubation in the cylinders. (Table 3). To compare, E. elongata $\alpha_{\text {ETR }}$ values showed 2 different significant results depending on the depth. $\alpha_{\text {ETR }}$ in algae collected from $0.5 \mathrm{~m}$ depth showed a significant increase at the nutrient-enriched site and in the $70 \%$ PAB treatment (Tables 2 \& 3). In contrast, algae collected from $2.0 \mathrm{~m}$ had higher $\alpha_{\mathrm{ETR}}$ values under the nonenriched treatment (Tables $2 \& 3$ ).
In C. tamariscifolia collected from $0.5 \mathrm{~m}$ depth, $E k_{\mathrm{ETR}}$ showed a significant interaction with nutrients and irradiance. In algae collected at $0.5 \mathrm{~m}$ depth under $70 \%$ PAB in the non-enriched treatment, $E k_{\mathrm{ETR}}$ was higher than in the other 3 combinations of treatments (Table 3). However, in algae collected from $2.0 \mathrm{~m}$ depth, $E k_{\mathrm{ETR}}$ did not show any significant differences (Table 2). On the other hand, in E. elongata, $E k_{\mathrm{ETR}}$ at both depths showed significant differences with the nutrients (Table 2). $E k_{\mathrm{ETR}}$ values for algae collected from $0.5 \mathrm{~m}$ depth were higher in nonenriched treatments, whereas in algae from $2.0 \mathrm{~m}$ depth, the values were higher in nutrient-enriched treatments (Table 2).

$\mathrm{NPQ}_{\max }$ in C. tamariscifolia showed significant differences due to nutrient treatments in algae collected from $0.5 \mathrm{~m}$ depth, and a significant interaction was observed with nutrients and irradiance in algae collected from $2.0 \mathrm{~m}$ depth (Table 2). In algae from both depths, $\mathrm{NPQ}_{\max }$ was higher in non-enriched treatments, whereas the $\mathrm{NPQ}_{\max }$ increased under $100 \%$ PAB conditions in algae collected from $2.0 \mathrm{~m}$ depth (Table 3). $\mathrm{NPQ}_{\max }$ did not show any significant differences among treatments in E. elongata (Table 2), in contrast to C. tamariscifolia which showed significant differences due to nutrients at both depths (Table 2). $E k_{\mathrm{NPQ}}$ values in algae collected from $0.5 \mathrm{~m}$ were higher in enriched treatments, whereas values were higher under non-enriched treatments in algae from $2.0 \mathrm{~m}$ (Table 3). Finally, $E k_{\mathrm{NPQ}}$ showed no significant differences among treatments in E. elongata (Table 2).

\section{Pigment content}

Chl a in C. tamariscifolia increased significantly when algae from $0.5 \mathrm{~m}$ depth were exposed to lower irradiance levels $\left(70 \% \%_{\mathrm{PAB}}\right.$ treatment). Similar results were found for chl $c$ in algae collected from $2.0 \mathrm{~m}$ (Tables $4 \& 5$ ). Chl $c$ content in C. tamariscifolia collected from $0.5 \mathrm{~m}$ was significantly higher in the nutrient-enriched treatment than in the non-enriched one (Tables $4 \& 5$ ). Chl $a$ and $c$ contents were initially higher in algae collected from $0.5 \mathrm{~m}$ (Table 5). Chl a in E. elongata did not present any significant differences among treatments (Tables $4 \& 5$ ).

PC content was significantly higher in the nutrientenriched treatment in E. elongata collected from $0.5 \mathrm{~m}$ depth. In contrast, PE content did not show any differences after the experiment (Tables 4 \& 5).

The carotenoids fucoxanthin and violaxanthin in C. tamariscifolia showed a significant increase under nutrient-enriched treatment in algae from $0.5 \mathrm{~m}$ depth 
Table 2. ANOVA results after in situ experiment testing for the effect of irradiance and nutrients on photosynthetic parameters of Cystoseira tamariscifolia and Ellisolandia elongata collected at 2 different depths. We used a significance level of $\alpha=0.05$, shown in bold. $F_{\mathrm{v}} / F_{\mathrm{m}}$ : maximal quantum yield, $\alpha_{\mathrm{ETR}}$ : photosynthetic efficiency, $\mathrm{ETR}_{\mathrm{max}}$ : maximal electron transport rate, $E k_{\mathrm{ETR}}:$ saturated irradiance of $E T R, N_{\text {max }}$ : maximal non-photochemical quenching, $E k_{\mathrm{NPQ}}$ : saturated irradiance of $\mathrm{NPQ}$

\begin{tabular}{|c|c|c|c|c|c|c|c|c|c|c|c|c|c|}
\hline & \multirow[t]{3}{*}{$\mathrm{df}$} & \multicolumn{6}{|c|}{ Cystoseira tamariscifolia } & \multicolumn{6}{|c|}{ Ellisolandia elongata } \\
\hline & & \multicolumn{3}{|c|}{$0.5 \mathrm{~m}$ depth } & \multicolumn{3}{|c|}{$2.0 \mathrm{~m}$ depth } & \multicolumn{3}{|c|}{$0.5 \mathrm{~m}$ depth } & \multicolumn{3}{|c|}{$2.0 \mathrm{~m}$ depth } \\
\hline & & MS & $F$ & $\mathrm{p}$ & MS & $F$ & $\mathrm{p}$ & MS & $F$ & $\mathrm{p}$ & MS & $F$ & $\mathrm{p}$ \\
\hline \multicolumn{14}{|l|}{$F_{\mathrm{v}} / F_{\mathrm{m}}$} \\
\hline Nutrients $(N)$ & 1 & 0.001 & 0.214 & 0.656 & 0.000 & 0.047 & 0.834 & 0.001 & 0.202 & 0.665 & 0.012 & 5.293 & 0.050 \\
\hline Irradiance $(E)$ & 1 & 0.005 & 1.228 & 0.300 & 0.002 & 0.702 & 0.426 & 0.000 & 0.156 & 0.703 & 0.005 & 2.129 & 0.183 \\
\hline$N \times E$ & 1 & 0.013 & 3.408 & 0.102 & 0.019 & 5.925 & 0.041 & 0.000 & 0.036 & 0.854 & 0.007 & 3.153 & 0.114 \\
\hline Residual & 8 & 0.004 & & & 0.003 & & & 0.003 & & & 0.002 & & \\
\hline \multicolumn{14}{|l|}{$\alpha_{\text {ETR }}$} \\
\hline Nutrients $(N)$ & 1 & 0.025 & 29.197 & 0.001 & 0.001 & 0.927 & 0.364 & 0.026 & 16.605 & 0.004 & 0.029 & 19.660 & 0.002 \\
\hline Irradiance $(E)$ & 1 & 0.002 & 2.948 & 0.124 & 0.001 & 1.076 & 0.330 & 0.009 & 5.491 & 0.047 & 0.006 & 4.160 & 0.076 \\
\hline$N \times E$ & 1 & 0.008 & 9.009 & 0.017 & 0.007 & 6.695 & 0.032 & 0.007 & 4.680 & 0.062 & 0.000 & 0.010 & 0.921 \\
\hline Residual & 8 & 0.001 & & & 0.001 & & & 0.002 & & & 0.001 & & \\
\hline \multicolumn{14}{|l|}{$\mathrm{ETR}_{\max }$} \\
\hline Nutrients $(N)$ & 1 & 2468.2 & 4.427 & 0.069 & 2320.8 & 4.728 & 0.061 & 0.122 & 0.294 & 0.602 & 0.009 & 0.019 & 0.895 \\
\hline Irradiance $(E)$ & 1 & 3773.9 & 6.769 & 0.032 & 2139.0 & 4.358 & 0.070 & 0.093 & 0.224 & 0.648 & 0.000 & 0.001 & 0.978 \\
\hline$N \times E$ & 1 & 345.6 & 0.620 & 0.454 & 710.5 & 1.448 & 0.263 & 0.110 & 0.264 & 0.621 & 0.017 & 0.036 & 0.854 \\
\hline Residual & 8 & 557.5 & & & 490.8 & & & 0.416 & & & 0.470 & & \\
\hline \multicolumn{14}{|l|}{$E k_{\mathrm{ETR}}$} \\
\hline Nutrients $(N)$ & 1 & 102164.0 & 20.450 & 0.002 & 27666.1 & 2.289 & 0.169 & 101.4 & 26.275 & $<0.001$ & 68.4 & 14.259 & 0.005 \\
\hline Irradiance $(E)$ & 1 & 82554.8 & 16.525 & 0.004 & 47574.2 & 3.937 & 0.083 & 8.4 & 2.188 & 0.177 & 18.2 & 3.796 & 0.087 \\
\hline$N \times E$ & 1 & 36962.9 & 7.399 & 0.026 & 288.0 & 0.024 & 0.881 & 3.9 & 1.019 & 0.342 & 8.7 & 1.819 & 0.214 \\
\hline Residual & 8 & 4995.8 & & & 12085.2 & & & 3.9 & & & 4.8 & & \\
\hline \multicolumn{14}{|l|}{$N P Q_{\max }$} \\
\hline Nutrients $(N)$ & 1 & 1.186 & 9.827 & 0.014 & 12.065 & 71.55 & $<0.001$ & 0.002 & 0.060 & 0.813 & 0.000 & 0.001 & 0.979 \\
\hline Irradiance $(E)$ & 1 & 0.000 & 0.002 & 0.969 & 0.883 & 5.234 & 0.051 & 0.000 & 0.004 & 0.951 & 0.001 & 0.066 & 0.803 \\
\hline $\mathrm{N} \times \mathrm{E}$ & 1 & 0.020 & 0.169 & 0.692 & 0.946 & 5.608 & 0.045 & 0.002 & 0.069 & 0.799 & 0.001 & 0.066 & 0.803 \\
\hline Residual & 8 & 0.121 & & & 0.169 & & & 0.033 & & & 0.021 & & \\
\hline \multicolumn{14}{|l|}{$E k_{\mathrm{NPQ}}$} \\
\hline Nutrients $(N)$ & 1 & 558682.0 & 13.364 & 0.006 & 11110334 & 94.365 & $<0.001$ & 113.6 & 0.578 & 0.469 & 79.1 & 0.154 & 0.705 \\
\hline Irradiance $(E)$ & 1 & 48629.6 & 1.163 & 0.312 & 609492.6 & 5.177 & 0.052 & 37.1 & 0.189 & 0.676 & 18.8 & 0.036 & 0.853 \\
\hline$N \times E$ & 1 & 9645.9 & 0.231 & 0.644 & 216.7 & 0.002 & 0.967 & 37.5 & 0.191 & 0.674 & 18.8 & 0.036 & 0.853 \\
\hline Residual & 8 & 41803.7 & & & 117737.9 & & & 196.5 & & & 515.2 & & \\
\hline
\end{tabular}

(Tables 4 \& 5). In contrast, carotenoid content in algae collected from $2.0 \mathrm{~m}$ depth was significantly higher the under $70 \%{ }_{\mathrm{PAB}}$ treatment (Tables 4 \& 5). Additionally, antheraxanthin and $\beta$-carotene in $C$. tamariscifolia collected at the same depth had a significant interaction between nutrients and irradiance. Both compounds increased significantly at $70 \% \%_{\mathrm{PAB}}$ in the non-enriched treatment site (Tables 4 \& 5). In E. elongata, fucoxanthin, antheraxanthin and $\beta$-carotene contents in algae collected from $0.5 \mathrm{~m}$ depth showed a significant increase in the $70 \%$ РАB irradiance treatment (Tables 4 \& 5). Additionally, fucoxanthin content increased significantly in algae cultured under nutrient-enrichment conditions (Tables 4 \& 5). Zeaxanthin content did not show any differences after the in situ experiment (Tables 4 \& 5) for either species.
Total phenolic compounds. Total phenolic compounds in C. tamariscifolia were significantly different among nutrient treatments in algae from both 0.5 and $2.0 \mathrm{~m}$ depths (Table 6). Additionally, algae collected from $2.0 \mathrm{~m}$ showed significant differences in both irradiance treatments (Table 6). In algae collected from $0.5 \mathrm{~m}$ depth, the total phenolic compounds were higher in the nutrient-enriched treatment (Fig. 4a). In C. tamariscifolia from $2.0 \mathrm{~m}$ depth, the increase of phenolic compounds was higher under $100 \%$ PAB than under $70 \% \%_{\mathrm{PAB}}$, whereas this increase was higher under non-enrichment than that under the enrichment treatment (Fig. 4a).

Antioxidant activity $\left(\mathbf{E C}_{\mathbf{5 0}}\right) \cdot \mathrm{EC}_{50}$ in C. tamariscifolia collected at $0.5 \mathrm{~m}$ depth showed a significant interaction between nutrients and irradiance 


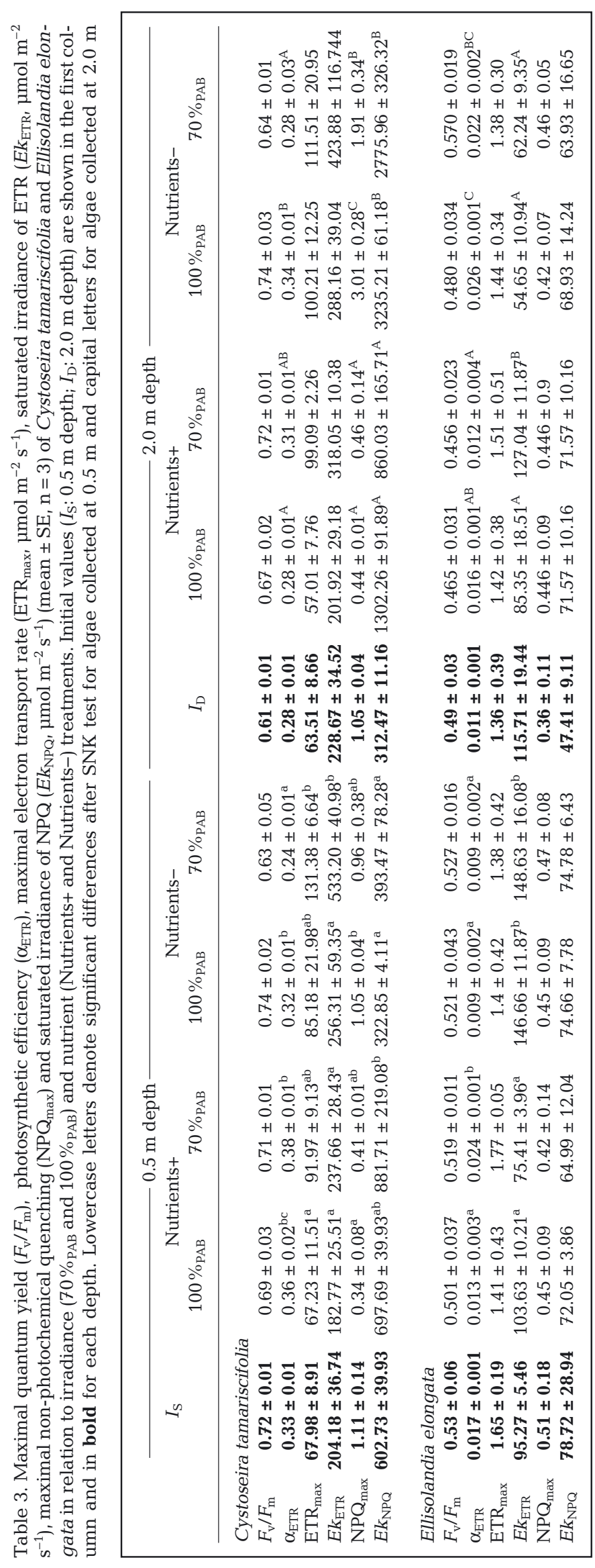

(Table 6). In the non-enriched treatment, $\mathrm{EC}_{50}$ was higher (lower antioxidant activity) than in the other treatment combinations (Fig. 4b). In algae collected at $2.0 \mathrm{~m}$ depth, significant differences were only found in nutrient-enriched treatments (Table 6), i.e. $\mathrm{EC}_{50}$ was higher (lower antioxidant activity) in the nutrient-enriched treatment (Fig. 4b) than in the non-enriched treatment.

Total MAA content. Total MAA content in E. elongata was higher in algae collected at $0.5 \mathrm{~m}$ depth than in those collected at $2.0 \mathrm{~m}$ (Fig. 5a). MAA content in algae from $0.5 \mathrm{~m}$ depth showed a significant increase under $100 \%$ РAB in nutrientenriched treatments (Table 7, Fig. 5a). In contrast, total MAA content in algae collected from $2.0 \mathrm{~m}$ depth was significantly higher at $100 \%$ РАВ for both enriched and non-enriched nutrient treatments (Table 7, Fig. 5a). The most abundant MAAs detected in this species were shinorine (50 to $60 \%$ ) and palythine (approx. 40\%), other MAAs such as asterina-330 were present in trace amounts. After the in situ experiment, algae collected from $2.0 \mathrm{~m}$ depth showed significantly higher palythine content under nutrient-enriched treatments, and shinorine increased in nonenriched treatments (Table 7, Fig. 5b,c). In contrast, algae collected from $0.5 \mathrm{~m}$ did not show any differences (Table 7).

\section{DISCUSSION}

We found high photoacclimation in Cystoseira tamariscifolia and Ellisolandia elongata, with photosynthetic parameters and biochemical composition changing in response to the short-term irradiance and nutrient treatments (60 h). The algae collected from $0.5 \mathrm{~m}$ depth had a higher production (ETR) and efficiency $\left(\alpha_{\text {ETR }}\right)$ than those from $2.0 \mathrm{~m}$ depth. These differences can be explained by the high transparency in the coastal waters of Cabo de Gata-Níjar Natural Park, allowing high penetration of both PAR and UVR, which can produce negative biological effects such as photoinhibition or DNA damage. In our study, the attenuation coefficients for PAR ( $\left.K d_{\mathrm{PAR}}\right)$ and UVA ( $\left.K d_{\mathrm{UVA}}\right)$ were $0.076 \mathrm{~m}^{-1}$ and $0.137 \mathrm{~m}^{-1}$, respectively. Figueroa \& Gómez (2001) described these coefficients with similar results for PAR $\left(K d_{\mathrm{PAR}}\right)$ and UVA $\left(K d_{\mathrm{UVA}}\right), \quad 0.070 \mathrm{~m}^{-1}$ and $0.100 \mathrm{~m}^{-1}$, respectively, and a $K d_{\mathrm{UVB}}$ value of $0.22 \mathrm{~m}^{-1}$ in the same coastal area. 
Table 4. ANOVA results after in situ experiment testing for the effect of irradiance and nutrients on the photosynthetic pigment content of Cystoseira tamariscifolia and Ellisolandia elongata collected at 2 different depths. We used a significance level of $\alpha=0.05$, shown in bold; nd: no data

\begin{tabular}{|c|c|c|c|c|c|c|c|c|c|c|c|c|c|}
\hline & \multirow[t]{3}{*}{ df } & \multicolumn{6}{|c|}{ Cystoseira tamariscifolia } & \multicolumn{6}{|c|}{ Corallina elongata } \\
\hline & & \multicolumn{3}{|c|}{$0.5 \mathrm{~m}$ depth } & \multicolumn{3}{|c|}{$2.0 \mathrm{~m} \mathrm{depth}$} & \multicolumn{3}{|c|}{$0.5 \mathrm{~m} \mathrm{depth}$} & \multicolumn{3}{|c|}{$2.0 \mathrm{~m}$ depth } \\
\hline & & MS & $F$ & $\mathrm{p}$ & MS & $F$ & $\mathrm{p}$ & MS & $F$ & $\mathrm{p}$ & MS & $F$ & $\mathrm{p}$ \\
\hline \multicolumn{14}{|l|}{ Chl a } \\
\hline Nutrients $(N)$ & 1 & 0.177 & 1.085 & 0.328 & 0.624 & 3.579 & 0.095 & 0.034 & 3.971 & 0.081 & & nd & \\
\hline Irradiance $(E)$ & 1 & 2.152 & 13.170 & 0.007 & 0.040 & 0.231 & 0.644 & 0.040 & 4.694 & 0.062 & & & \\
\hline$N \times E$ & 1 & 0.038 & 0.233 & 0.642 & 0.770 & 4.416 & 0.069 & 0.005 & 0.635 & 0.448 & & & \\
\hline Residual & 8 & 0.163 & & & 0.174 & & & 0.009 & & & & & \\
\hline \multicolumn{14}{|l|}{$\mathrm{Chl} C$} \\
\hline Nutrients $(N)$ & 1 & 0.015 & 7.653 & 0.024 & 0.000 & 0.162 & 0.698 & & nd & & & nd & \\
\hline Irradiance $(E)$ & 1 & 0.000 & 0.064 & 0.807 & 0.012 & 6.201 & 0.038 & & & & & & \\
\hline$N \times E$ & 1 & 0.000 & 0.002 & 0.963 & 0.001 & 0.318 & 0.588 & & & & & & \\
\hline Residual & 8 & 0.002 & & & 0.002 & & & & & & & & \\
\hline \multicolumn{14}{|l|}{ Phycoerythrin } \\
\hline Nutrients $(N)$ & 1 & & nd & & & nd & & 0.860 & 3.418 & 0.102 & & nd & \\
\hline Irradiance $(E)$ & 1 & & & & & & & 0.421 & 1.672 & 0.232 & & & \\
\hline$N \times E$ & 1 & & & & & & & 0.017 & 0.066 & 0.803 & & & \\
\hline Residual & 8 & & & & & & & 0.252 & & & & & \\
\hline \multicolumn{14}{|l|}{ Phycocyanin } \\
\hline Nutrients $(N)$ & 1 & & nd & & & nd & & 0.067 & 5.903 & 0.041 & & nd & \\
\hline Irradiance $(E)$ & 1 & & & & & & & 0.06 & 5.31 & 0.05 & & & \\
\hline$N \times E$ & 1 & & & & & & & 0.001 & 0.113 & 0.745 & & & \\
\hline Residual & 8 & & & & & & & 0.011 & & & & & \\
\hline \multicolumn{14}{|l|}{ Fucoxanthin } \\
\hline Nutrients $(N)$ & 1 & 184106.8 & 9.560 & 0.015 & 4812.6 & 0.229 & 0.645 & 36.41 & 6.890 & 0.030 & & nd & \\
\hline Irradiance $(E)$ & 1 & 2085.6 & 0.108 & 0.751 & 132991.1 & 6.328 & 0.036 & 78.77 & 14.904 & 0.005 & & & \\
\hline$N \times E$ & 1 & 256.3 & 0.013 & 0.911 & 4799.9 & 0.228 & 0.646 & 5.92 & 1.120 & 0.321 & & & \\
\hline Residual & 8 & 19257.5 & & & 21016.5 & & & 5.29 & & & & & \\
\hline \multicolumn{14}{|l|}{ Violoxanthin } \\
\hline Nutrients $(N)$ & 1 & 3327.25 & 13.924 & 0.006 & 6.55 & 0.032 & 0.863 & 0.102 & 1.326 & 0.283 & & nd & \\
\hline Irradiance $(E)$ & 1 & 1.74 & 0.007 & 0.934 & 2108.12 & 10.235 & 0.013 & 0.200 & 2.590 & 0.146 & & & \\
\hline$N \times E$ & 1 & 18.83 & 0.079 & 0.786 & 107.35 & 0.521 & 0.491 & 0.150 & 1.950 & 0.200 & & & \\
\hline Residual & 8 & 238.96 & & & 205.98 & & & 0.077 & & & & & \\
\hline \multicolumn{14}{|l|}{ Anteraxanthin } \\
\hline Nutrients $(N)$ & 1 & 0.08 & 0.004 & 0.953 & 43.88 & 28.707 & 0.001 & 89.32 & 4.422 & 0.069 & & nd & \\
\hline Irradiance $(E)$ & 1 & 31.07 & 1.460 & 0.261 & 2.62 & 1.713 & 0.227 & 204.13 & 10.106 & 0.013 & & & \\
\hline$N \times E$ & 1 & 7.77 & 0.365 & 0.562 & 9.00 & 5.885 & 0.041 & 3.59 & 0.178 & 0.684 & & & \\
\hline Residual & 8 & 21.28 & & & 1.53 & & & 20.20 & & & & & \\
\hline \multicolumn{14}{|l|}{ Zeaxanthin } \\
\hline Nutrients $(N)$ & 1 & 54.69 & 1.455 & 0.262 & 2.02 & 0.066 & 0.804 & 3.58 & 1.727 & 0.225 & & nd & \\
\hline Irradiance $(E)$ & 1 & 0.06 & 0.002 & 0.969 & 0.55 & 0.018 & 0.896 & 4.67 & 2.257 & 0.171 & & & \\
\hline$N \times E$ & 1 & 85.64 & 2.278 & 0.170 & 9.10 & 0.297 & 0.601 & 0.41 & 0.199 & 0.667 & & & \\
\hline Residual & 8 & 37.59 & & & 30.63 & & & 2.07 & & & & & \\
\hline \multicolumn{14}{|l|}{$\beta$-carotene } \\
\hline Nutrients $(N)$ & 1 & 623.87 & 6.230 & 0.037 & 328.83 & 7.710 & 0.024 & 13.12 & 4.432 & 0.068 & & nd & \\
\hline Irradiance $(E)$ & 1 & 97.13 & 0.970 & 0.354 & 58.13 & 1.363 & 0.277 & 45.76 & 15.465 & 0.004 & & & \\
\hline$N \times E$ & 1 & 457.29 & 4.566 & 0.065 & 1016.02 & 23.821 & 0.001 & 2.32 & 0.785 & 0.401 & & & \\
\hline Residual & 8 & 100.14 & & & 42.65 & & & 2.96 & & & & & \\
\hline
\end{tabular}




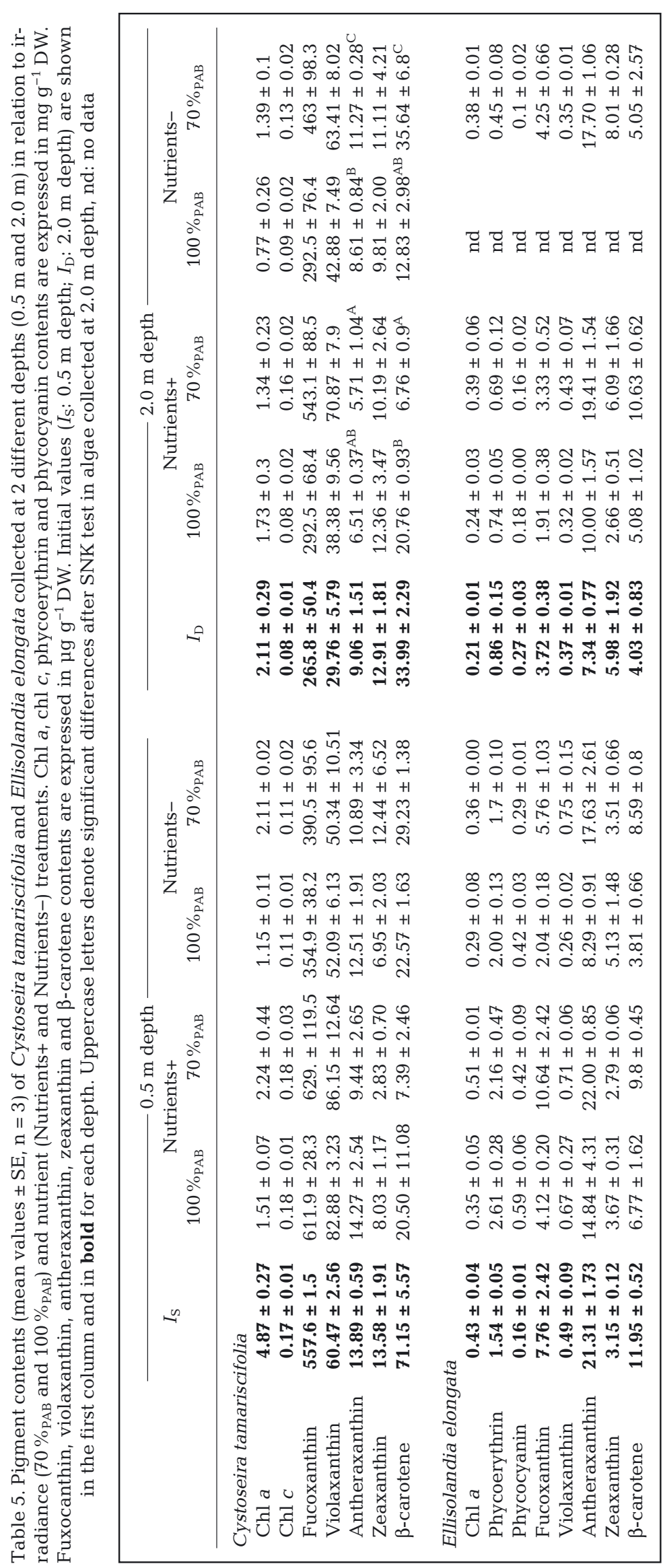

The C:N ratio was more favorable physiologically $(<23)$ in $C$. tamariscifolia from $0.5 \mathrm{~m}$ than in algae from $2.0 \mathrm{~m}(>30)$. On the other hand, the elevated $\mathrm{NPQ}_{\max }$ indicated high photoprotection capacity. The suntype photosynthetic pattern of the species analyzed is shown by the high $E k_{\mathrm{ETR}}$ values (200 to $220 \mu \mathrm{mol}$ photons $\mathrm{m}^{-2} \mathrm{~s}^{-1}$ ) in algae collected at both 0.5 and $2.0 \mathrm{~m}$ (initial conditions). These values were lower than those reported by Celis-Plá (2011) and Figueroa et al. (2014, this Theme Section) in $C$. tamariscifolia growing in a nearby coastal area of the Mediterranean Sea but subjected to emersion conditions, in contrast to the subtidal species of Cabo de Gata-Níjar, i.e. higher nutrient and irradiance levels than those found in this study.

According to the physiological status, algae grown at $0.5 \mathrm{~m}$ will be less vulnerable to higher irradiance conditions $\left(100 \%_{\mathrm{PAB}}\right)$ than algae grown at $2.0 \mathrm{~m}$. At the initial natural conditions, the phenolic compounds (photoprotectors) in C. tamariscifolia are expected to be higher in algae grown at $0.5 \mathrm{~m}$ than at $2.0 \mathrm{~m}$. However, in algae collected at $0.5 \mathrm{~m}$ depth, the phenolic compounds were lower than algae collected at $2.0 \mathrm{~m}$, during the initial period. This can be explained as a consequence of the high irradiance found at $0.5 \mathrm{~m}$, since phenolic compounds could be released under high solar irradiance, preventing the photodamage as a photoprotection strategy (Abdala-Díaz et al. 2006). Photoacclimation responses were also affected by nitrate supply in general; nitrate enrichment increased the photosynthetic rate and the accumulation of photoprotectors. This indicates that the algae are nutrient-limited in this oligotrophic system (Figueroa \& Gómez 2001).

C. tamariscifolia collected from $0.5 \mathrm{~m}$ depth maintained ETR values $60 \mathrm{~h}$ after transferring to $100 \%_{\mathrm{PAB}}$ in both nutrient conditions, but phenolic compounds and internal $\mathrm{N}$ content increased only in nutrientenriched conditions. The transplantation to $70 \%_{\text {РАв }}$ provoked an increase in ETR max $_{1}$ indicating that algae at $0.5 \mathrm{~m}$ depth were photoinhibited under initial conditions. The increase of $\mathrm{ETR}_{\max }$ at $70 \%_{\mathrm{PAB}}$ is related to a decrease in $\mathrm{NPQ}_{\max }$, indicating less energy dissipation as a consequence of decreased 
Table 6. ANOVA results after in situ experiment testing for the effect of irradiance and nutrients on the phenolic compounds and antioxidant activity $\left(\mathrm{EC}_{50}\right)$ of Cystoseira tamariscifolia collected at 2 different depths. We used a significance level of $\alpha=0.05$, shown in bold

\begin{tabular}{|lcccccccc|}
\hline & df & \multicolumn{3}{c}{0.5 m depth } & \multicolumn{3}{c|}{2.0 m depth } \\
& \multicolumn{1}{c}{ MS } & $F$ & $\mathrm{p}$ & $\mathrm{MS}$ & $F$ & $\mathrm{p}$ \\
\hline \multicolumn{3}{l}{ Phenolic compounds } \\
\multicolumn{2}{c}{ Nutrients $(N)$} & 1 & $\mathbf{2 6 2 . 2}$ & $\mathbf{7 . 9 5 6}$ & $\mathbf{0 . 0 2 2}$ & $\mathbf{1 0 7 . 7}$ & $\mathbf{5 . 9 5 5}$ & $\mathbf{0 . 0 4 1}$ \\
Irradiance $(E)$ & 1 & 30.1 & 0.912 & 0.367 & $\mathbf{3 3 1 . 7}$ & $\mathbf{1 8 . 3 4 6}$ & $\mathbf{0 . 0 0 3}$ \\
$N \times E$ & 1 & 36.1 & 1.094 & 0.326 & 0.3 & 0.014 & 0.908 \\
Residual & 8 & 33.0 & & & 18.1 & & \\
& & & & & & & \\
EC & & & & & & & \\
Nutrients $(N)$ & 1 & 0.014 & 1.417 & 0.268 & $\mathbf{0 . 0 9 4}$ & $\mathbf{1 0 . 8 6}$ & $\mathbf{0 . 0 1 1}$ \\
Irradiance $(E)$ & 1 & 0.032 & 3.273 & 0.108 & 0.001 & 0.078 & 0.787 \\
$N \times E$ & 1 & $\mathbf{0 . 0 6 8}$ & $\mathbf{6 . 9 1 8}$ & $\mathbf{0 . 0 3 0}$ & 0.034 & 3.919 & 0.083 \\
Residual & 8 & 0.010 & & & 0.009 & & \\
\hline
\end{tabular}
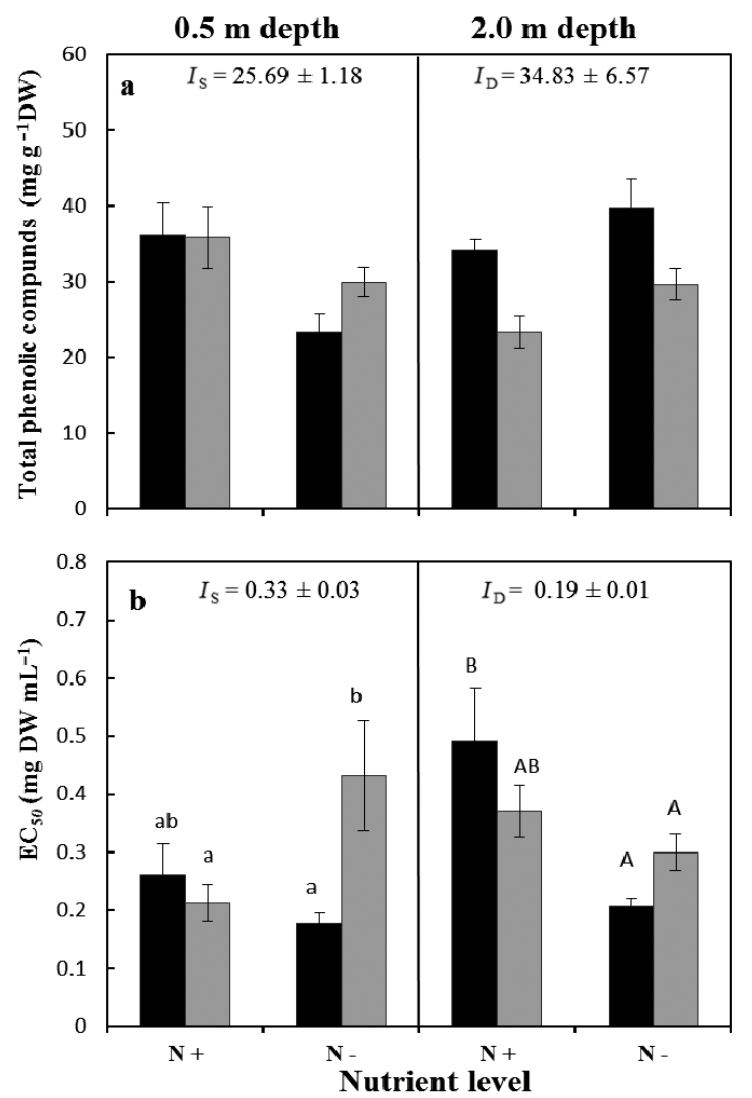

Fig. 4. (a) Total phenolic compounds and (b) antioxidant activity $\left(\mathrm{EC}_{50}\right)($ mean $\pm \mathrm{SE}, \mathrm{n}=3$ ) of Cystoseira tamariscifolia from 0.5 and $2.0 \mathrm{~m}$ depths under irradiance and nutrient treatments. Black bars indicate $100 \%_{\mathrm{PAB}}$, and grey bars indicate $70 \%_{\text {PAB }}$. N+ and $\mathrm{N}$ - indicate nutrient-enriched and non-enriched treatments, respectively. Upper values in each box indicate initial values $\left(I_{\mathrm{S}}: 0.5 \mathrm{~m}\right.$ depth; $I_{\mathrm{D}}: 2.0 \mathrm{~m}$ depth). Lowercase letters denote significant differences after SNK test for algae collected at $0.5 \mathrm{~m}$ depth and capital letters for algae collected at $2.0 \mathrm{~m}$
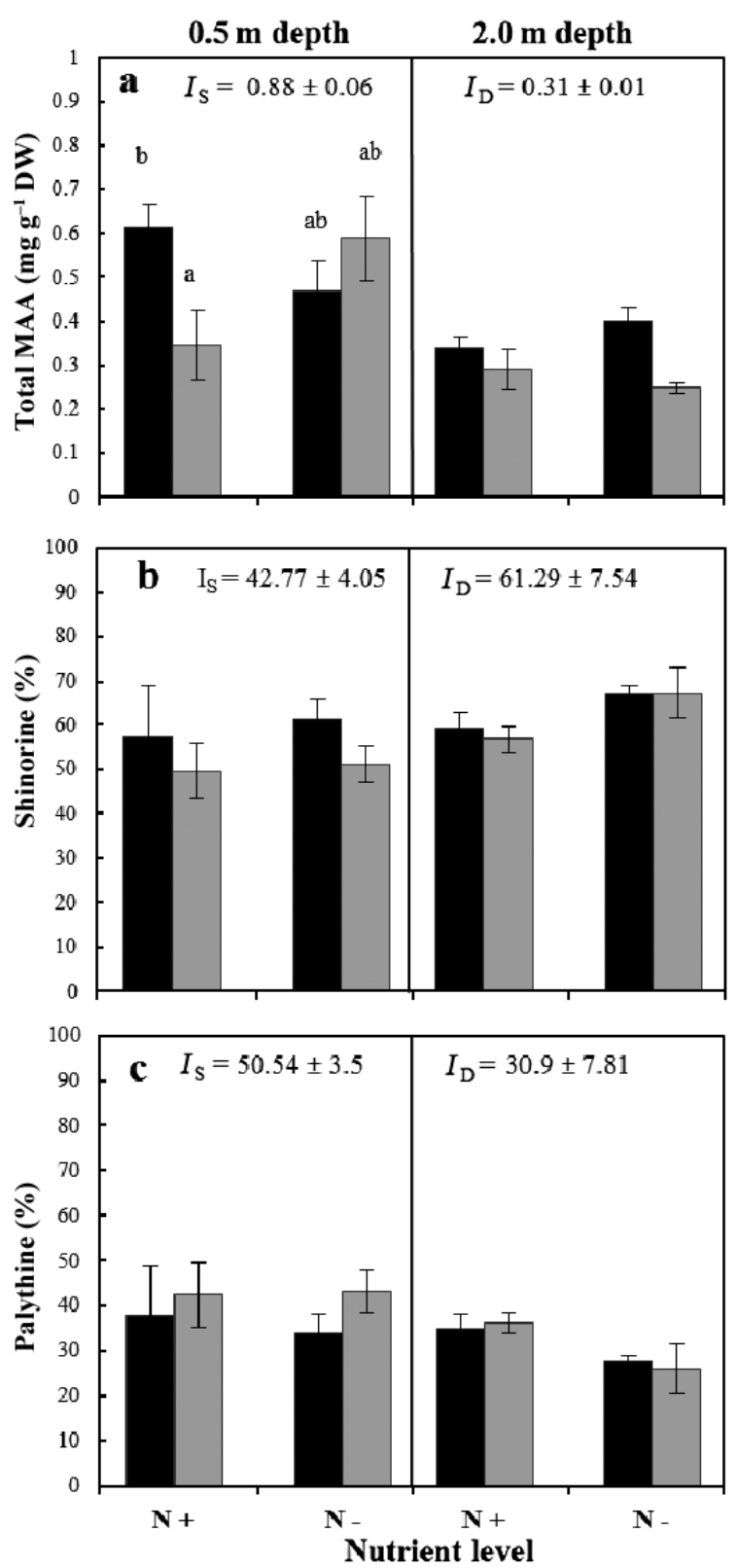

Fig. 5. (a) Total mycosporine-like amino acid (MAA) content and percentages of (b) shinorine and (c) palythine (mean values $\pm \mathrm{SE}, \mathrm{n}=3$ ) in Ellisolandia elongata from 0.5 and $2.0 \mathrm{~m}$ depth under irradiance and nutrient treatments. Black bars indicate $100 \%_{\mathrm{PAB}_{1}}$ and grey bars indicate $70 \%_{\mathrm{PAB}}$. N+ and Nindicate nutrient-enriched and non-enriched treatments, respectively. Upper values in each box indicate initial values $\left(I_{\mathrm{S}}: 0.5 \mathrm{~m}\right.$ depth; $I_{\mathrm{D}}: 2.0 \mathrm{~m}$ depth). Lowercase letters denote significant differences after SNK test

irradiance, at least in the short-term period analyzed. In any case, prolonged time can eventually reduce the values of ETR $R_{\max }$ due to less available energy at $2.0 \mathrm{~m}$ than that at $0.5 \mathrm{~m}$ in spite of photoinhibition. The $\mathrm{ETR}_{\max }$ of algae collected from $2.0 \mathrm{~m}$ depth when transplanted to $100 \%_{\mathrm{PAB}}$ increased only in non- 
Table 7. ANOVA results after in situ experiment testing for the effect of irradiance and nutrients on total mycosporine-like amino acid (MAA) content, and percentages of shinorine and palythine of Ellisolandia elongata collected at 2 different depths. We used a significance level of $\alpha=0.05$, shown in bold

\begin{tabular}{|lrrrrrrr|}
\hline & df & \multicolumn{3}{c}{0.5 m depth } & \multicolumn{3}{c|}{2.0 m depth } \\
& & MS & $F$ & $\mathrm{p}$ & $\mathrm{MS}$ & $F$ & $\mathrm{p}$ \\
\hline \multicolumn{2}{l}{ Total MAA content } & & & & & & \\
Nutrients $(N)$ & 1 & 0.008 & 0.427 & 0.532 & 0.000 & 0.096 & 0.764 \\
Irradiance $(E)$ & 1 & 0.016 & 0.917 & 0.366 & $\mathbf{0 . 0 3 0}$ & $\mathbf{1 0 . 4 5 3}$ & $\mathbf{0 . 0 1 2}$ \\
$N \times E$ & 1 & $\mathbf{0 . 1 1 4}$ & $\mathbf{6 . 4 7 1}$ & $\mathbf{0 . 0 3 5}$ & 0.008 & 2.857 & 0.129 \\
Residual & 8 & 0.018 & & & 0.003 & & \\
\% Shinorine & & & & & & & \\
Nutrients $(N)$ & 1 & 24.93 & 0.151 & 0.708 & $\mathbf{2 5 2 . 6 1}$ & $\mathbf{5 . 9 2}$ & $\mathbf{0 . 0 4 1}$ \\
Irradiance $(E)$ & 1 & 239.16 & 1.448 & 0.263 & 4.81 & 0.113 & 0.746 \\
$N \times E$ & 1 & 6.09 & 0.037 & 0.852 & 4.88 & 0.114 & 0.744 \\
Residual & 8 & 165.13 & & & 42.69 & & \\
\% Palythine & & & & & & & \\
Nutrients $(N)$ & 1 & 8.21 & 0.051 & 0.827 & $\mathbf{2 3 0 . 5 2}$ & $\mathbf{6 . 3 5}$ & $\mathbf{0 . 0 3 6}$ \\
Irradiance $(E)$ & 1 & 143.23 & 0.885 & 0.374 & 0.14 & 0.004 & 0.952 \\
$N \times E$ & 1 & 18.23 & 0.113 & 0.746 & 7.84 & 0.216 & 0.654 \\
Residual & 8 & 161.87 & & & 36.28 & & \\
\hline
\end{tabular}

treatments; however, the internal $\mathrm{N}$ content decreased in both nutrient treatments. The transplantation of algae collected from $2.0 \mathrm{~m}$ depth to $70 \%$ PAB caused a higher $\alpha_{\text {ETR }}$ and ETR $_{\max }$ in both nutrient conditions; however, internal $\mathrm{N}$ content and MAAs increased in nutrient-enriched conditions.

In general, in both species collected from $0.5 \mathrm{~m}$ depth, the addition of nutrients increased their photosynthetic efficiency. The photosynthetic response was also affected by irradiance levels. Although the initial values of $\mathrm{NPQ}_{\max }$ in C. tamariscifolia were similar, $N P Q_{\max }$ decayed at both depths under nutrient enrichment and $E k_{\mathrm{NPQ}}$ only increased in the enriched treatment. Furthermore, in C. tamariscifolia collected at $2.0 \mathrm{~m}$ depth, an interaction between light and nutrients was observed, where transplanted algae (to 100\% $\%_{\mathrm{PAB}}$ ) under nonenriched treatment showed an increase in $N P Q_{\max }$ and $E k_{\mathrm{NPQ}}$ in all treatments. At high nutrient availability, it seems that algae collected from $0.5 \mathrm{~m}$ depth had higher levels of

enriched treatments, but both internal $\mathrm{N}$ and phenolic compound contents increased under nutrient enrichment.

PAR and UVR can cause photoinhibition, which can be defined as the light-dependent decline in photosynthetic capacity and maximal photosynthetic efficiency as a consequence of the dominance of photodamage versus photorepair processes (Osmond 1994, Gómez et al. 2004). It is also thought that photoinhibition is a down-regulation mechanism to quench excessive solar energy (Demmig-Adams et al. 2008). However, in C. tamariscifolia, no photoinhibition was observed. Intertidal macroalgae from southern Spain have low photoinhibition at noon and high recovery capacity during daily cycles due to high energy dissipation (Figueroa et al. 1997, Häder et al. 1997, 1998).

Photosynthetic efficiency $\alpha_{\mathrm{ETR}}$, ETR $_{\max }$ and MAAs in E. elongata collected from $0.5 \mathrm{~m}$ depth decreased after transfer to $100 \%$ РАВ under both nutrient conditions, but internal $\mathrm{N}$ contents increased only under nutrient-enriched conditions. The transplant to $70 \%$ PAB provoked an increase of $\alpha_{\text {ETR }}$ and $\mathrm{ETR}_{\max }$ only under nutrient-enriched conditions; however, internal $\mathrm{N}$ content and MAAs decreased in both nutrient treatments, indicating that algae grown at $0.5 \mathrm{~m}$ depth can be photoinhibited under initial conditions. The level of ETR $\mathrm{Exax}, \alpha_{\mathrm{ETR}}$ and MAAs in algae collected from $2.0 \mathrm{~m}$ depth increased when they were transplanted to $100 \%$ PAB under both nutrient photoprotective compounds (phenols) or increased size of antenna (higher content of chl $c$ and fucoxanthin were observed). This could be due to high antioxidant activity and less requirement for the dissipation of energy in the form of heat (low $\mathrm{NPQ}_{\mathrm{max}}$ ) or due to less UV radiation that could be reaching the photosynthetic apparatus. However, in C. tamariscifolia collected at $2 \mathrm{~m}$ depth after the transplant conditions $\left(70 \%{ }_{\mathrm{PAB}}\right)$, high levels of accessory pigments were found. These differences were independent of the nutrient treatment. The phenolic compounds and antioxidant activity were affected by irradiance and nutrients as single factors in the first case, and by the interaction of both factors in the second case. For the other carotenoids, similar results were found in C. tamariscifolia collected from $0.5 \mathrm{~m}$ depth.

Carotenoid contents were less influenced by irradiance or nutrients with the exception of violaxanthin that had higher content after nutrient enrichment. On the other hand, in C. tamariscifolia collected from $2.0 \mathrm{~m}$ depth, violaxanthin content was higher in the simulated deeper irradiance $\left(70 \%{ }_{\mathrm{PAB}}\right)$, as was found in other accessory pigments. However, antheraxanthin and $\beta$-carotene were significantly affected by the interaction of irradiance and nutrients. In E. elongata collected from $0.5 \mathrm{~m}$ depth, an effect of irradiance was found. The responses found in this study for both species are similar to those described by Demmig-Adams \& Adams (1996). The response of the xanthophyll cycle and light absorption could re- 
flect a regulatory and photoprotective response that down-regulates the delivery of excitation energy into the electron-transport chain to match the rates at which products of electron transport can be consumed in these leaves. Goss \& Jakob (2010) indicate that the xanthophyll cycle represents an important photoprotection mechanism in plant cells. This suggests a relationship between higher photosynthetic rates and a higher activity of the xanthophyll cycle. However, the presence of a functional xanthophyll cycle in red algae is uncertain (Andersson et al. 2006, Schubert et al. 2006). In fact, the predominant presence of red algae in intertidal zones and coral reefs suggests a highly efficient capacity to withstand elevated irradiance levels and large diurnal light fluctuations due to tides and aerial exposure (Schubert et al. 2011).

E. elongata possesses high reflectance under high solar radiation, allowing it to live in areas of high radiation and sun exposure due to a skeleton composition of calcium carbonate (Häder et al. 1997). These authors described a high reflectance under high solar radiation exposure in $E$. elongata, which can be advantageous under elevated solar irradiance reducing photoinhibition in this species.

Connan et al. (2004) found higher levels of phenols in summer in several brown macroalgae off Brittany related to higher solar irradiance. Similarly, AbdalaDíaz et al. (2006) found higher phenol content in summer than in winter in C. tamariscifolia collected in southern Spain in the morning. However, at noon the levels were similar in both seasons due to the high release of polyphenols in summer. In our study, the phenolic content in C. tamariscifolia increased with nutrient enrichment in algae collected at $0.5 \mathrm{~m}$ depth in the non-enriched treatment and in transplanted specimens (to $100 \%_{\mathrm{PAB}}$ ) under non-enrichment treatments in those collected from $2.0 \mathrm{~m}$ depth. In brown algae, UV screen compounds (polyphenols) accumulate under high PAR and UVR and these compounds have strong antioxidant activity (Pavia et al. 1997, Connan et al. 2004, Cruces et al. 2012). This may suggest that this is probably more related to the nitrate availability than to solar irradiance conditions. Pavia \& Toth (2000) indicate that the $\mathrm{N}$ content can enhance the accumulation of phenolic compounds in some brown algae. In fact, concentrations of phenolic compounds show phenotypic plasticity in response to changes in environmental parameters, such as salinity, nutrients, light quality and availability, and intensity of herbivores (Peckol et al. 1996, Pavia et al. 1997, Pavia \& Toth 2000, Honkanen et al. 2002, Swanson \& Druehl 2002, Amsler \& Fairhead
2006). Moreover, C. tamariscifolia had higher antioxidant activity at $0.5 \mathrm{~m}$ depth in transplanted conditions $(70 \%$ РАВ $)$ without nutrient enrichment, and also in algae collected from $2.0 \mathrm{~m}$ depth in transplant conditions $\left(100 \%_{\mathrm{PAB}}\right)$ with nutrient enrichment.

As has been mentioned, the response of E. elongata collected from $0.5 \mathrm{~m}$ depth was dependent mostly on irradiance. However, the content of MAAs (UV-screening substance) of algae collected at $0.5 \mathrm{~m}$ depth depended on the interaction between irradiance and nutrients, as reported by Korbee-Peinado et al. (2004). Karsten et al. (1998) and Franklin et al. (2001) have shown that accumulation of MAAs depend on both quality and quantity of radiation, with higher accumulation of MAAs with high daily PAR doses and UV exposure. Korbee-Peinado et al. (2004) found that high ammonium concentrations significantly increased the content of MAAs in Pyropia columbina (as Porphyra columbina). In their study, an interaction between irradiance and nutrients was found. Similar results were found for other Porphyra species, Grateloupia lanceola and Gracilaria spp. (Korbee et al. 2005a, Huovinen et al. 2006, Barufi et al. 2011, Figueroa et al. 2012). In our study, the MAA total content decreased in algae transplanted from $100 \%_{\mathrm{PAB}}$ to $70 \%_{\mathrm{PAB}}$ and after nutrient enrichment, whereas no effect of nutrient was observed in algae collected from $2.0 \mathrm{~m}$ depth waters. It seems that the short-term effect of the nutrient addition is not enough to produce an increase of total MAA content under nitrogen-enriched conditions as has been reported in other algae (Barufi et al. 2011, Figueroa et al. 2012). However, the effect of nutrients was reflected by a preferential accumulation of some types of MAAs, but only in E. elongata collected from $2.0 \mathrm{~m}$ depth. The relative content of palythine increased in nutrient-enriched algae, which has been associated with higher antioxidant activities compared to shinorine (de la Coba et al. 2009).

In conclusion, C. tamariscifolia and E. elongata showed different physiological responses under different nutrient and irradiance conditions. Few interactive effects between these 2 physical stressors were found, suggesting major additive effects on the responses of both species. In fact, environmental variables acting in additive forms can act as more powerful stress factors (Martínez et al. 2012) leading to changes in the physiology of these macroalgae. Therefore, understanding the physiological consequences of the potential additive effects of these physical stressors on these dominant species is needed to predict future environmental fluctuations related to climate change. 
Acknowledgements. We thank the office of the 'Cabo de Gata-Nijar' Natural Park of the Junta de Andalucía for the use of their facilities. The financial contributions to the GAP 9 workshop 'Influence of the pulsed-supply of nitrogen on primary productivity in phytoplankton and marine macrophytes: an experimental approach' by Walz GmbH (including the use of several PAM fluorometers), Redox, the University of Málaga General Foundation, the Ministry of Economy and Competitivity of Spain Government (Acción Complementaria CTM2011-15659-E) and the Spanish Institute of Oceanography are extremely appreciated. P.S.M.C.-P. gratefully acknowledges financial support from 'BecasChile' (CONICYT) of the Chilean Ministry of Education. We thank the reviewers for their helpful and constructive comments which significantly improved the manuscript. We also thank Dr. Jason Hall-Spencer for English corrections.

\section{LITERATURE CITED}

Abdala-Díaz RT, Cabello-Pasini A, Pérez-Rodríguez E, Conde-Álvarez RM, Figueroa FL (2006) Daily and seasonal variations of optimum quantum yield and phenolic compounds in Cystoseira tamariscifolia (Phaeophyta). Mar Biol 148:459-465

> Algarra P, Niell FX (1987) Structural adaptations to light reception in two morphotypes of Corallina elongata Ellis \& Soland. Mar Ecol 8:253-261

- Amsler CD, Fairhead VA (2006) Defensive and sensory chemical ecology of brown algae. Adv Bot Res 43:1-91

Andersson M, Schubert H, Pedersen M (2006) Different patterns of carotenoid composition and photosynthesis acclimation in two tropical red algae. Mar Biol 149: 653-665

Arévalo R, Pinedo S, Ballesteros E (2007) Changes in the composition and structure of Mediterranean rocky-shore communities following a gradient of nutrient enrichment: descriptive study and test of proposed methods to assess water quality regarding macroalgae. Mar Pollut Bull 55:104-113

> Arnold TM, Targett NM (2002) Marine tannins: the importance of a mechanistic framework for predicting ecological roles. J Chem Ecol 28:1919-1934

Ballesteros E, Torras X, Pinedo S, García M, Mangialajo L, de Torres M (2007) A new methodology based on littoral community cartography dominated by macroalgae for the implementation of the European Water Framework Directive. Mar Pollut Bull 55:172-180

Barufi JB, Korbee N, Oliveira MC, Figueroa FL (2011) Effects of $\mathrm{N}$ supply on the accumulation of photosynthetic pigments and photoprotectors in Gracilaria tenuistipitata (Rhodophyta) cultured under UV radiation. J Appl Phycol 23:457-466

Bermejo R, De la Fuente G, Vergara JJ, Hernández I (2013) Application of the CARLIT index along a biogeographical gradient in the Alboran Sea (European Coast). Mar Pollut Bull 72:107-118

Bischof K, Gómez I, Molis M, Hanelt D and others (2006) Ultraviolet radiation shapes seaweed communities. Rev Environ Sci Biotechnol 5:141-166

> Blois MS (1958) Antioxidant determinations by the use of a stable free radical. Nature 181:1199-1200

> Braga JC, Vescogni A, Bosellini FR, Aguirre J (2009) Coralline algae (Corallinales, Rhodophyta) in western and central Mediterranean Messinian reefs. Palaeogeogr
Palaeoclimatol Palaeoecol 275:113-128

Celis-Plá P (2011) Fotoaclimatación y valoración del estrés oxidativo de Cystoseira tamariscifolia (Hudson) Papenfuss (Phaeophyceae, Fucales), efectos de la radiación y nutrientes. MSc thesis, University of Barcelona

Connan S, Goulard F, Stiger V, Deslandes E, Ar-Gall E (2004) Interspecific and temporal variation in phlorotannin levels in an assemblage of brown algae. Bot Mar 47: $410-416$

> Connan S, Delisle F, Deslandes E, Ar-Gall E (2006) Intrathallus phlorotannin content and antioxidant activity in Phaeophyceae of temperate waters. Bot Mar 49:39-46

> Conolly NJ, Drew EA (1985) Physiology of Laminaria. III. Effect of a coastal eutrophication gradient on seasonal patterns of growth and tissue composition in L. digitata Lamour and L. saccharina (L.) Lamour. Mar Ecol (Berl) 6: 181-195

> Cruces E, Huovinen P, Gómez I (2012) Phlorotannin and antioxidant responses upon short-term exposure to UV radiation and elevated temperature in three south Pacific kelps. Photochem Photobiol 88:58-66

> Davison IR, Pearson GA (1996) Stress tolerance in intertidal seaweeds. J Phycol 32:197-211

de la Coba F, Aguilera J, Figueroa FL, De Gálvez MV, Herrera E (2009) Antioxidant activity of mycosporine-like amino acids isolated from three red macroalgae and one marine lichen. J Appl Phycol 21:161-169

> Demmig-Adams B, Adams WW (1996) Xanthophyll cycle and light stress in nature: uniform response to excess direct sunlight among higher plant species. Planta 198: 460-470

Demmig-Adams B, Dumlao MR, Herzenach MK, Adams WW (2008) Acclimation. Elsevier, University of Colorado, Boulder, CO

Eilers PHC, Peeters JCH (1988) A model for the relationship between light intensity and the rate of photosynthesis in phytoplankton. Ecol Modell 42:199-215

> Figueroa FL, Gómez I (2001) Photoacclimation to solar UV radiation in red macroalgae. J Appl Phycol 13:233-248

> Figueroa FL, Salles S, Aguilera J, Jiménez C and others (1997) Effects of solar radiation on photoinhibition and pigmentation in the red alga Porphyra leucosticta. Mar Ecol Prog Ser 151:81-90

Figueroa FL, Conde-Álvarez R, Gómez I (2003) Relations between electron transport rates determined by pulse amplitude modulated chlorophyll fluorescence and oxygen evolution in macroalgae under different light conditions. Photosynth Res 75:259-275

Figueroa FL, Martínez B, Israel A, Neori A and others (2009) Acclimation of Red Sea macroalgae to solar radiation: photosynthesis and thallus absorptance. Aquat Biol 7: 159-172

> Figueroa FL, Korbee N, Abdala R, Jerez CG and others (2012) Biofiltration of fishpond effuents and accumulation of N-compounds (phycobiliproteins and mycosporine-like amino acids) versus C-compounds (polysaccharides) in Hydropuntia cornea (Rhodophyta). Mar Pollut Bull 64:310-318

Figueroa FL, Bonomi Barufi J, Malta EJ, Conde-Álvarez R and others (2014) Short-term effects of incrasing $\mathrm{CO}_{2}$, nitrate and temperature on three Mediterranean macroalgae: biochemical composition. Aquat Biol 22:195-212

> Flores-Moya A, Gómez I, Viñegla B, Altamirano M and others (1998) Effects of solar radiation on the endemic Mediterranean red alga Rissoella verrucosa: photosynthetic 
performance, pigment content and the activities of enzymes related to nutrient uptake. New Phytol 139: 673-683

Folin O, Ciocalteu V (1927) On tyrosine and tryptophane determinations in proteins. J Biol Chem 12:239-243

Franklin LA, Kräbs G, Kuhlenkamp R (2001) Blue light and UVA radiation control the synthesis of mycosporine-like amino acids in Chondrus crispus (Florideophyceae). J Phycol 37:257-270

> García-Sánchez M, Korbee N, Pérez-Ruzafa IM, Marcos C, Domínguez B, Figueroa FL, Pérez-Ruzafa A (2012) Physiological response and photoacclimation capacity of Caulerpa prolifera (Forsskål) J.V. Lamouroux and Cymodocea nodosa (Ucria) Ascherson meadows in the Mar Menor lagoon (SE Spain). Mar Environ Res 79:37-47

Gómez I, López-Figueroa F, Ulloa N, Morales V, Lovengreen C, Huovinen P, Hess S (2004) Patterns of photosynthesis in 18 species of intertidal macroalgae from southern Chile. Mar Ecol Prog Ser 270:103-116

Gómez I, Wulff A, Roleda MY, Huovinen P and others (2011) Light and temperature demands of marine benthic microalgae and seaweeds in polar regions. In: Wiencke C (ed) Biology of polar benthic algae. De Gruyter, Berlin, p 195-220

Gómez-Garreta A, Barceló-Marti M, Gallardo T, PérezRuzafa IM, Ribera MA, Rull J (2001) Flora phycologica ibérica, Fucales, Vol 1. Universidad de Murcia, España

> Goss R, Jakob T (2010) Regulation and function of xanthophyll cycle-dependent photoprotection in algae. Photosynth Res 106:103-122

Grzymski J, Johnsen G, Sakshug E (1997) The signifcance of intracellular self-shading on the bio-optical properties of brown, red and green macroalgae. J Phycol 33:408-414

Häder DP, Lebert M, Flores-Moya A, Jiménez C and others (1997) Effect of solar radiation on the photosynthetic activity of the red alga Corallina elongata Ellis et Soland. Photochem Photobiol 37:196-202

> Häder DP, Lebert M, Figueroa FL, Jiménez C, Viñegla B, Perez-Rodríguez E (1998) Photoinhibition in Mediterranean macroalgae by solar radiation measured on site by PAM fluorescence. Aquat Bot 61:225-236

Hanelt D, Figueroa FL (2012) Physiological and photomorphogenic effects of light of marine macrophytes. In: Wienke C, Bischof K (eds) Seaweed biology, Ecological studies, Springer, Berlin, p 3-23

> Hanisak MD (1979) Nitrogen limitation of Codium fragile ssp. tomentosoides determined by tissue analysis. Mar Biol 50:333-337

Helmuth B, Harley CDG, Halpin PM, O'Donnell M, Hofmann GE, Blanchette C (2002) Climate change and latitudinal patterns of intertidal thermal stress. Science 298: 1015-1017

> Helmuth B, Mieszkowska N, Moore P, Hawkins SJ (2006) Living on the edge of two changing worlds: forecasting the response of rocky intertidal ecosystems to climate change. Annu Rev Ecol Evol Syst 37:373-404

Hoegh-Guldberg O, Bruno JF (2010) The impact of climate change on the world's marine ecosystems. Science 328: 1523-1528

Honkanen T, Jormalainen V, Hemmi A, Mäkinen A, Heikkilä N (2002) Feeding and growth of the isopod Idotea baltica on the brown alga Fucus vesiculosus: roles of inter-population and within-plant variation in plant quality. Ecoscience 9:332-338

- Huovinen P, Gómez I (2011) Spectral attenuation of solar radiation in Patagonian fjord and coastal waters and implications for algal photobiology. Cont Shelf Res 31: 254-259

Huovinen P, Matos J, Pinto IS, Figueroa FL (2006) The role of ammonium in photoprotection against high irradiance in the red alga Grateloupia lanceola. Aquat Bot 84:308-316

Jones A (1997) Environmental biology. Routledge, London

> Karsten U, Franklin LA, Lüning K, Wiencke C (1998) Natural ultraviolet and photosynthetic active radiations induce formation of mycosporine-like amino acids in the marine macroalga Chondrus crispus (Rhodophyta). Planta 205: 257-262

Korbee N, Huovinen P, Figueroa FL, Aguilera J, Karsten U (2005a) Availability of ammonium influences photosynthesis and the accumulation of mycosporine-like amino acids in two Porphyra species (Bangiales, Rhodophyta). Mar Biol 146:645-654

Korbee N, Figueroa FL, Aguilera J (2005b) Effect of light quality on the accumulation of photosynthetic pigments, proteins and mycosporine-like amino acids in the red alga Porphyra leucosticta (Bangiales, Rhodophyta). J Photochem Photobiol B 80:71-78

> Korbee-Peinado N, Abdala-Díaz RT, Figueroa FL, Helbling EW (2004) Ammonium and UV radiation simulate the accumulation of mycosporine-like amino acids in Porphyra columbina (Rhodophyta) from Patagonia, Argentina. J Phycol 40:248-259

Koroleff F (1983) Determination of phosphorus. In: Grasshoff K, Ehrhardt M, Kremling K (eds) Methods of seawater analysis: second, revised and extended edition. VerlagChemie, Weinheim, p 125-139

Lobban CS, Harrison PJ (1994) Seaweed ecology and physiology. Cambridge University Press, Cambridge

Martínez B, Rico JM (2002) Seasonal variation of P content and major $\mathrm{N}$ pools in Palmaria palmata (Rhodophyta). J Phycol 38:1082-1089

> Martínez B, Arenas F, Rubal M, Burgués S and others (2012) Physical factors driving intertidal macroalgae distribution: physiological stress of a dominant fucoid at its southern limit. Oecologia 170:341-353

> Marzinelli EM, Zagal CJ, Chapman MG, Underwood AJ (2009) Do modified habitats have direct or indirect effects on epifauna? Ecology 90:2948-2955

Marzinelli EM, Underwood AJ, Coleman RA (2011) Modified habitats influence kelp epibiota via direct and indirect effects. PLoS ONE 6:e21936

Nygard CA, Dring MJ (2008) Influence of salinity, temperature and dissolved inorganic carbon and nutrient concentration on the photosynthesis and growth of Fucus vesiculosus from the Baltic and Irish Seas. Eur J Phycol 43:253-262

Osmond CB (1994) What is photoinhibition? Some insights from comparisons of shade and sun plants. In: Baker NR, Bowyer JR (eds) Photoinhibition of photosynthesis, from molecular mechanisms to the field. Bios Scientific Publ Oxford, Oxford, p 1-24

Pavia H, Toth GB (2000) Inducible chemical resistance to herbivory in the brown seaweed Ascophyllum nodosum. Ecology 81:3212-3225

Pavia H, Cervin G, Lindgren A, Aberg P (1997) Effects of UV-B radiation and simulated herbivory on phlorotannins in the brown alga Ascophylum nodosum. Mar Ecol Prog Ser 157:139-146

> Peckol P, Krane JM, Yates JL (1996) Interactive effects of inducible defense and resource availability on phloro- 
tannins in the North Atlantic brown alga Fucus vesiculosus. Mar Ecol Prog Ser 138:209-217

Pedersen MF, Borum J (1997) Nutrient control of estuarine macroalgae: growth strategy and the balance between nitrogen requirements and uptake. Mar Ecol Prog Ser 161:155-163

Pérez-Lloréns JL, Vergara JJ, Pino RR, Hernandez I, Peralta G, Niell FX (1996) The effect of photoacclimation on the photosynthetic physiology of Ulva curvata and Ulva rotundata (Ulvales, Chlorophyta). Eur J Phycol 31: 349-359

Quintano E, Ganzedo U, Díez I, Figueroa FL, Gorostiaga JM (2013) Solar radiation (PAR and UVA) and water temperature in relation to biochemical performance of Gelidium corneum (Gelidiales, Rhodophyta) in subtidal bottoms off the Basque coast. J Sea Res 83:47-55

Rodríguez C, Polo L (1986) Fenologia y distribució de les algues del litral Catalá. Scientia Gerundensis 12:67-86

Sampath-Wiley P, Neefus CD (2007) An improved method for estimating R-phycoerythrin and R-phycocyanin contents from crude aqueous extracts of Porphyra (Bangiales, Rhodophyta). J Appl Phycol 19:123-129

Schreiber U, Endo T, Mi H, Asada K (1995) Quenching analysis of chlorophyll fluorescence by the saturation pulse method: particular aspects relating to the study of eukaryotic algae and cyanobacteria. Plant Cell Physiol 36:873-882

Schubert N, García-Mendoza E, Pacheco-Ruiz I (2006) Carotenoid composition of marine red algae. J Phycol 42: 1208-1216

Schubert N, Garía-Mendoza E, Enríquez S (2011) Is the photo-acclimatory response of Rhodophyta conditioned

Submitted: December 12, 2013; Accepted: May 6, 2014 by the species carotenoid profile? Limnol Oceanogr 56: 2347-2361

Sorte CJB, Williams S, Zerebecki R (2010) Ocean warming increases threat of invasive species in a marine fouling community. Ecology 91:2198-2204

Southward AJ, Hawkins SJ, Burrows MT (1995) Seventy years' observations of changes in distribution and abundance of zooplankton and intertidal organisms in the western English Channel in relation to rising sea temperature. J Therm Biol 20:127-155

Swanson AK, Druehl LD (2002) Induction, exudation and the UV protective role of kelp phlorotannins. Aquat Bot 73: 241-253

Teichberg M, Fox SE, Aguila C, Olsen YS, Valiela I (2008) Macroalgal responses to experimental nutrient enrichment in shallow coastal waters: growth, internal nutrient pools, and isotopic signatures. Mar Ecol Prog Ser 368: $117-126$

Underwood T (1997) Experiments in ecology. Their logical design and interpretation using analysis of variance. Cambridge University Press, Cambridge

> Vergara JJ, Bird KT, Niell FX (1995) Nitrogen assimilation following $\mathrm{NH} 4+$ pulses in the red alga Gracilariopsis lemaneiformis: effect on C metabolism. Mar Ecol Prog Ser 122:253-263

Wellburn A (1994) The spectral determination of chlorophylls $a$ and $b$, as well as total carotenoids, using various solvents with spectrophotometers of different resolution. J Plant Physiol 144:307-313

> Xenopoulos MA, Frost PC, Elser JJ (2002) Joint effects of UV radiation and phosphorus supply on algal growth rate and elemental composition. Ecology 83:423-435

Proofs received from author(s): August 6, 2014 